\title{
Nanotechnology and COVID-19: quo vadis?
}

\author{
João Lima Tavares • Iago Dillion Lima Cavalcanti • \\ Nereide Stela Santos Magalhães • Mariane Cajubá de Britto Lira Nogueira
}

Received: 5 October 2021 / Accepted: 1 March 2022 / Published online: 7 March 2022

(C) The Author(s), under exclusive licence to Springer Nature B.V. 2022

\begin{abstract}
The pandemic COVID-19 has worried everyone due to the high mortality rate and the high number of people hospitalized with severe acute respiratory syndrome caused by SARS-CoV-2. Given the seriousness of this disease, several companies and research institutions have sought alternative treatment and/or prevention methods for COVID-19. Due to its versatility, nanotechnology has allowed the development of protective equipment and vaccines to prevent the disease and reduce the number of severe COVID19 cases. Thus, this article combined the main works and products developed in a nanotechnological field for COVID-19. We performed a literature search using the keywords "COVID-19," "SARS-CoV-2," "nanoparticles," "nanotechnology," and "liposomes" in the SciELO, Scifinder, PubMed, Sciencedirect, ClinicalTrials, and Nanotechnology Products databases Database. The data survey indicated 48 articles, 62 products, and 32 patents. The use of nanotechnology against COVID-19 has brought benefits
\end{abstract}

J. L. Tavares · I. D. L. Cavalcanti ·

N. S. Santos Magalhães · M. C. Lira Nogueira ( $\square)$

Laboratório de Imunopatologia Keizo-Asami (LIKA),

Universidade Federal de Pernambuco (UFPE), Av.

Prof. Moraes Rego, Cidade Universitária, Recife,

PE 123550670-901, Brazil

e-mail: mariane.lira@ufpe.br

J. L. Tavares - I. D. L. Cavalcanti - M. C. Lira Nogueira Laboratório de Nanotecnologia, Biotecnologia e Cultura de Células, Centro Acadêmico de Vitória, Universidade Federal de Pernambuco (CAV/UFPE), Recife, Brazil in several parameters of this disease, helping develop rapid diagnostic tests that release the result in $10 \mathrm{~min}$, as well as developing vaccines containing genetic material from SARS-CoV-2 (DNA, mRNA, and protein subunits). Nanotechnology is an exceptional ally against COVID-19, contributing to the most diverse areas, helping both prevent, diagnose, and treat COVID-19.

Keywords COVID-19 - Nanomedicine · Nanocarriers $\cdot$ Liposomes $\cdot$ Nanoparticles

\section{Introduction}

The world is currently facing one of humanity's greatest crises, the crisis of the new coronavirus (SARS-CoV-2). The world has recently experienced other viral epidemics, such as SARS-CoV in 2002, H1N1 in 2009, and MERS-CoV in 2012 (Munster et al. 2020). However, the respiratory disease that emerged in China in December 2019 in just a few months reached frightening global proportions. This led the World Health Organization (WHO) to declare coronavirus disease (COVID-19) as a pandemic in March 2020, and after 17 months, reached numbers such as 215,714,824 cases and 4,490,753 deaths (data obtained on August 31, 2021) (WHO. World Health Organization. Coronavirus disease 2019 (COVID19) situation report - 2019). Although some countries have been without cases of community transmission 
for a few months (Fig. 1), the pandemic is not over yet, and tens of thousands of people still die every day. This scenario impels worldwide scientists in an urgent search for new information about this new and unknown pathogen (Kostarelos 2020).

The virus that causes severe acute respiratory syndrome (SARS) is a virus of the coronavirida family with a long positive RNA chain, with a diameter of 60 to $100 \mathrm{~nm}$, and an envelope that presents characteristic spikes of the spike protein. The entry of this pathogen into human cells is carried out through the interaction between viral membrane proteins and ECA2 and CD147 receptors of pulmonary epithelium cells and macrophages, respectively (Zhang et al. 2020a). According to one of the general characteristics of the viruses, SARS-CoV-2 mutates, quickly generating several different variant strains. Currently, about 5775 variants have already been identified (Bhat, et al. 2021). Among these variants, the Brazilian variant $\mathrm{P} 1$ stands out for its increased potential for transmissibility (Dejnirattisai et al. 2021).

Currently, some unknowns of the pandemic have already been solved thanks to the enormous advances caused by the joint efforts of the entire scientific community worldwide. Among these advances, the rapid sequencing of the SARSCoV-2 genome allowed the development of better techniques for diagnosing COVID-19, and one of the most significant advances was the development of vaccines that have enabled the application of more than 750 million doses around the world (WHO. World Health Organization. Coronavirus disease 2019 (cOVID-19) situation report - 2019). However, despite these advances, there is still much to be discovered to increase the effectiveness of diagnostics, protective equipment, and new vaccines. Also, there is a great need for effective treatment since the lack of this is one of the main factors that make the fight against this disease a challenge to reduce mortality and hospitalizations (Kostarelos 2020).

In the constant search for solutions for COVID19, nanotechnology has shown itself as a valuable and relevant choice (Chan 2020). By definition, nanotechnology is the science of manipulating structures at the nanoscale that can be used in various products, including medical, cosmetics, and food (Poole and Owens 2010; FDA 2020). Therefore, this emerging technology opens doors to endless opportunities to fight this disease. The use of nanotechnology in the health area has been observed in several applications. One application is developing drug delivery systems: nanocarriers capable of carrying and releasing drugs directly into

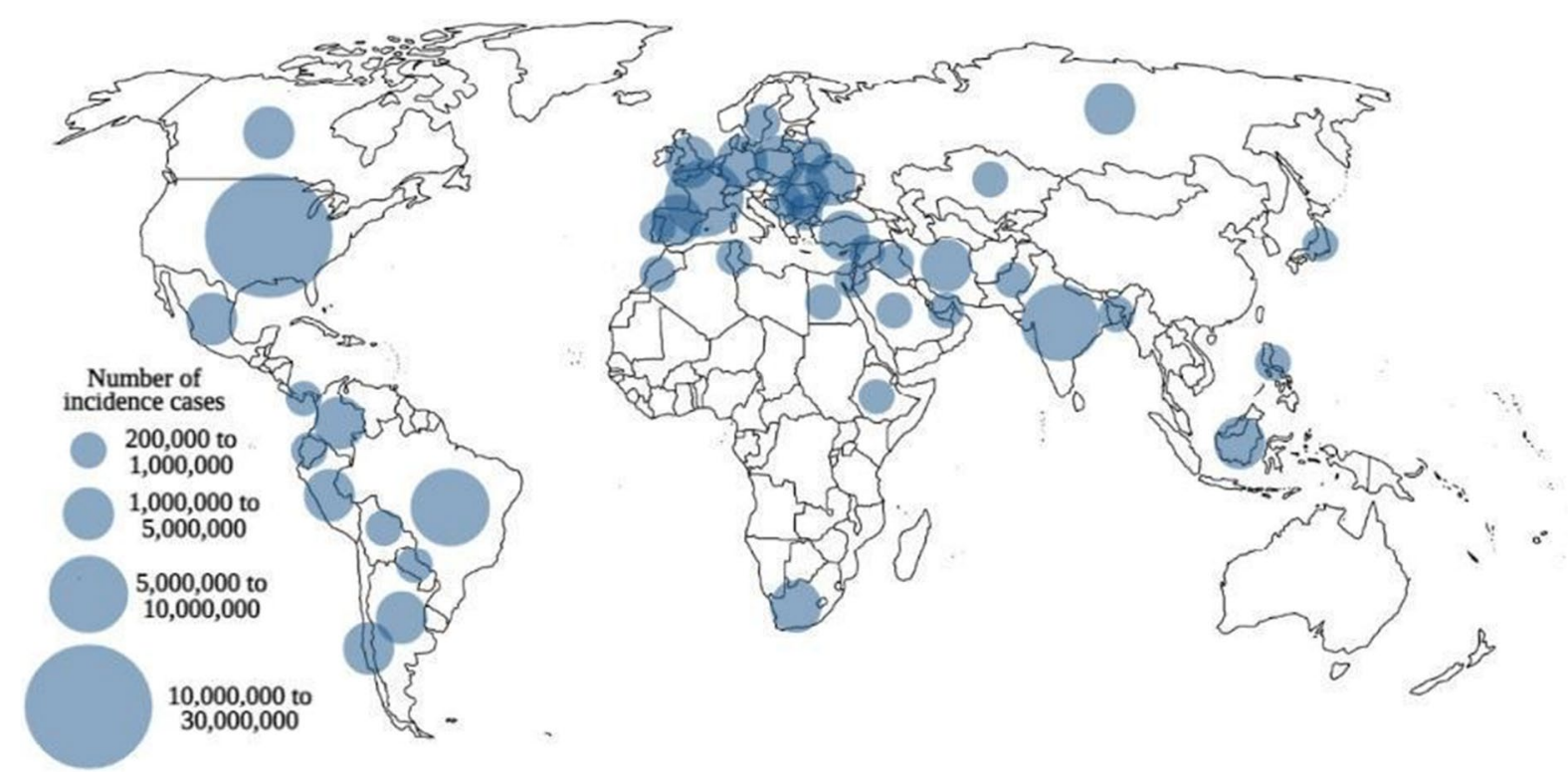

Fig. 1 Bubble diagram for the number of COVID-19 cases worldwide. Source: Adapted from (WHO. World Health Organization. Coronavirus disease 2019 (COVID-19) situation report - 2019) 
their respective target tissue (Vasir et al. 2005) for the treatment, diagnosis, or both.

Understanding the potential applications of nanosystems against SARS-CoV-2 is essential, as it opens up several possibilities in combating this disease. In this framework, monitoring nanotechnology innovations is mandatory, as COVID-19 remains a global health problem. In this manuscript, therefore, we summarize the latest findings on the use of nanosystems in this pandemic, looking forward to advancing (quo vadis?) using nanotechnology.

Therefore, we carried out this descriptive literature review based on the following databases: Scientific Electronic Library Online (SciELO), Scifinder, National Institute of Industrial Property (INPI), ClinicalTrials, US National Library of Medicine National Institutes of Health (PubMed), Sciencedirect, and Nanotechnology Products Database (NPD). The SciELO, Scifinder, PubMed, and ScienceDirect databases allowed us to survey the main articles in the health area on the subject, as well as the Scifinder and Clinical Trials allowed us to analyze clinical studies involving nanotechnology products for COVID-19, and INPI databases allowed us to survey the main published patents and the NPD platform to survey nanotechnology products proposed for COVID-19.

The research in the databases was carried out by crossing the descriptors, in English, "COVID-19," "SARS-CoV-2," "nanoparticles," "nanotechnology," and "liposomes" available in the Descriptors in Health Sciences (DeCS).

After the initial research, the inclusion and exclusion criteria were applied. Inclusion criteria were research articles published in 2020-2021, available electronically, full text, and written in English. Also, it included data from companies and clinical studies developing and testing nanotechnological products to treat or prevent COVID-19. The exclusion criteria used were duplicate articles in the databases, review articles, abstracts of congresses, naps, editorials, monographs, dissertations, short communications, and theses. Also, was excluded articles that, although addressed on COVID-19, did not correlate with nanotechnology, products that dealt with nanotechnology but have no application for COVID-19, and clinical studies that do not focus on the implementation in pharmaceutical nanotechnology for the diagnosis, treatment, and prevention of COVID-19. After this, the final sample of articles was tabulated and plotted using Microsoft Excel software and GraphPad Prism 8.

\section{Overview of nanotechnology products for COVID-19}

An initial sample of 593 manuscripts was searched. A total of 48 articles were considered after applying the inclusion and exclusion criteria. In parallel, 62 nanotechnology-based products were selected from the Nanotechnology Products Database (NPD) platform. In Fig. 2, is observed a significant increase in the $R \& D$ and commercialization of nanotechnologybased products after the COVID-19 pandemic. The impact of the pandemic on the investment in nanotechnology with marketed healthcare products was impressive.

It is noteworthy from 2020 to 2021, an increase of more than $50 \%$ of nanotechnology-based products was verified, with 62 products placed on the market for the prevention, diagnosis, treatment, and protection against COVID-19, compared to that occurred in the last thirty years ( $<1993$ to 2019), with the launch of only 53 nanotechnology-based products, aimed at the diagnosis and treatment of diseases.

After data tabulation, graphs that allow a clear interpretation were plotted. Using the date of product registration published on the NPD platform, we observed the profile of monthly disclosure of

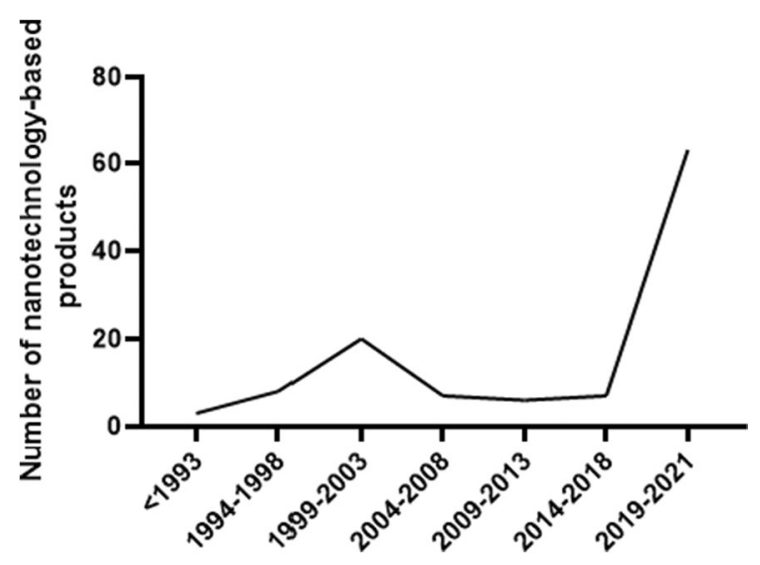

Fig. 2 Growth of nanotechnology products after the COVID19 pandemic. Source: (Anselmo and Mitragotri 2019; Bobo et al. 2016; Caster et al. 2016; Farjadian et al. 2019; Nanotechnology Products Database 2020) 
products based on nanotechnology proposed for COVID-19 during the year 2020 (Fig. 3). The development of nanotechnology-based products started to appear in March, representing 11.29\%. In April, there was a considerable increase in product registration, representing $37.09 \%$ of all products, reflecting the relevance of the nanotechnology field for COVID-19.

A comparison was established between the number of articles, considering the acceptance data, for each month of the years 2020-2021 (Fig. 3). It is worth mentioning that the date of article acceptance was chosen due to the considerable delay in the publication. A large discrepancy between the date of acceptance and publication of articles could result in an erroneous interpretation of the frequency of articles available. As the first COVID-19 nanotechnologybased product appeared in March, the first publication on the subject also rose in March 2020 (6.25\% publications) (Fig. 4). Most of the nanosystems publications concerning COVID-19 were in July 2020 and February 2021, accounting for $12.50 \%$ of publications for both months, followed by October and December 2020 with $10.42 \%$ of publications.

Figure 5 shows a great diversity of nanosystems being used in different ways to obtain medicines, vaccines, personal protective equipment (PPEs), and other efficient products against the SARS-CoV-2 virus. However, it is notable that despite the great diversity of systems, nanoparticles are highly prevalent and have been used in more than $50 \%$ of the selected articles. We highlight the metallic nanoparticles present in $32 \%$ of the developed products. Mainly products aimed at the diagnosis and development of PPEs and, in second place, the polymeric nanoparticles present in $12 \%$ of the designed products, their use focused more on products aimed at the treatment
Fig. 3 The number of nanotechnology-based products registered for use in COVID-19 according to the month of their registration. Source: (Nanotechnology Products Database 2020)
Fig. 4 Publication profile of nanotechnology and COVID-19 according to the month of acceptance date. Source: Research data
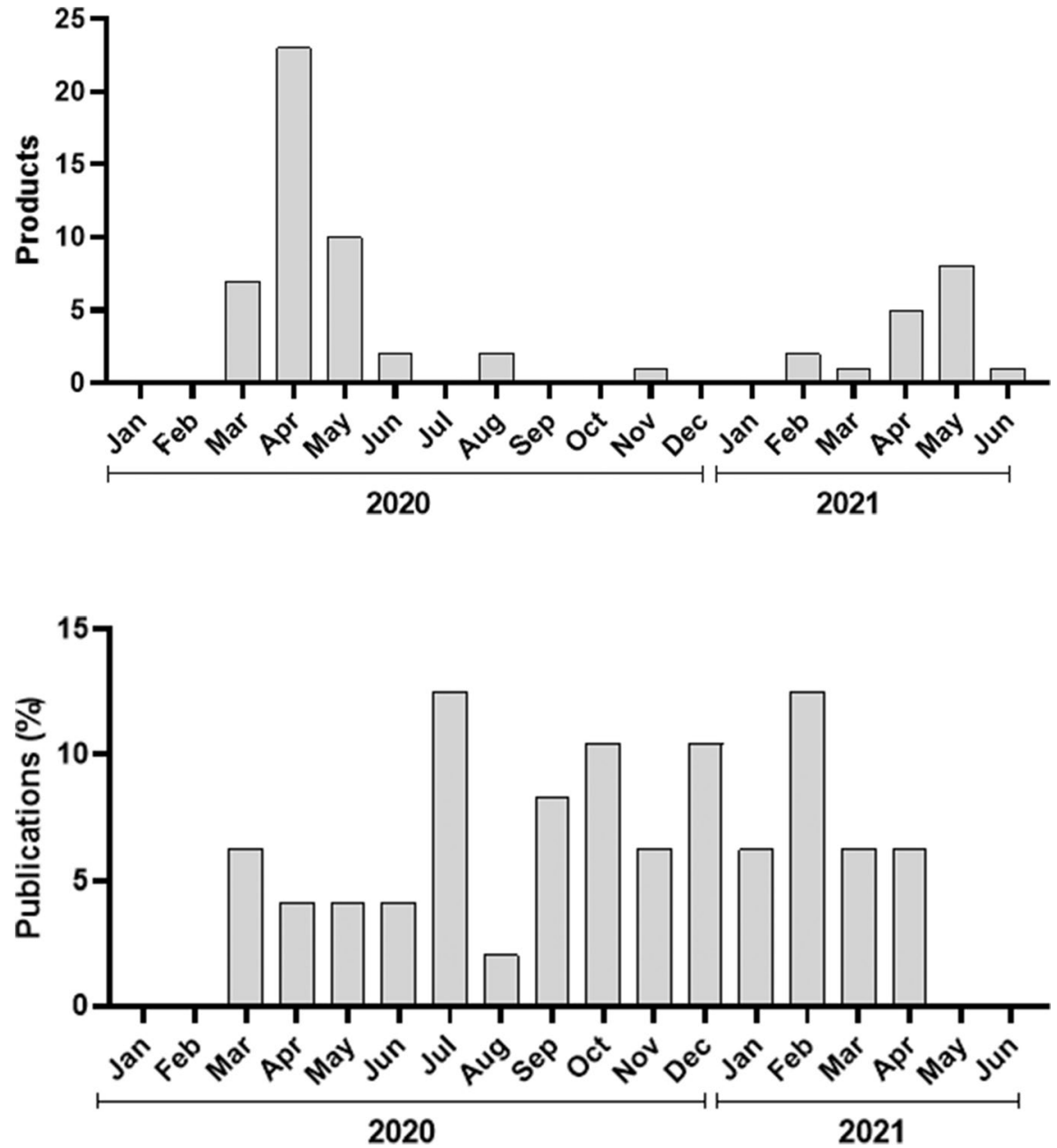


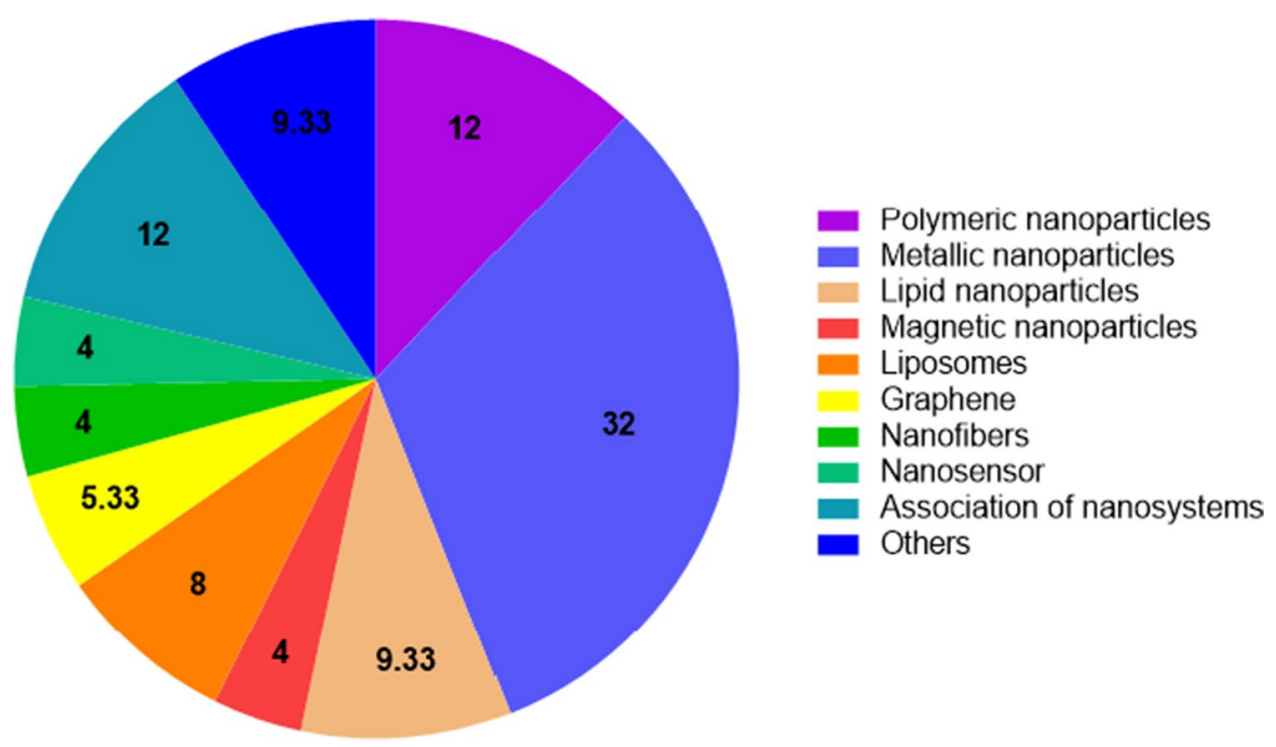

Fig. 5 Percentage of nano-based products used against COVID-19. Source: Research data

and/or prevention of COVID-19. Due to the large number of publications concerning nanoparticles than other nanocarriers, a greater focus on this nanosystem was done.

We also searched patent filings associated with nanotechnological products for the application against COVID-19. It is worth noting that China is responsible for the largest number of patents filed, representing $81.25 \%$. Gold nanoparticles and liposomes are the most studied regarding nanosystems, each representing $18.75 \%$ of patents. Regarding the proposed products, $46.88 \%$ of the patents are for vaccines containing antibodies against SARS-CoV-2 coupled to nanoparticles or mRNA encapsulated in liposomes for inducing antibodies against SARS-CoV-2 (Table 1).

Diagnosis and treatment of COVID-19

Testing for COVID-19 is of crucial importance. It allows for a quick diagnosis of the disease and provides isolation on the part of the infected patient to prevent contamination of more people. Even more importantly, testing provides the number of infected daily, vital information for the control and monitoring the disease by health organizations (Udugama et al. 2020).

Several different methods have been developed to achieve diagnosis by different routes. Among these techniques, it is possible to observe molecular, clinical, imaging, and immunological diagnosis.

Although there is a wide range of different methods, some are used more. One of the most important tests is the reverse transcription-polymerase chain reaction (RT-PCR). This test is based on detecting SARS-CoV-2 genetic material in the patient's sample, so it is extremely specific and is considered the gold standard for diagnosing COVID-19. This technique involves the reverse transcription of the viral RNA in a complementary DNA (cDNA) strand, followed by amplifying specific regions of that strand. During the amplification stage, fluorescent markers are added to each replicated sequence. These markers allow identifying and quantifying these sequences using computers and light sensors (Udugama et al. 2020; Shih et al. 2020).

Several kits used to diagnose COVID-19 are based on RT-PCR, being possible after sequencing the genome of SARS-CoV-2. Some targeted genes include the $\mathrm{E}$ gene (encodes the envelope protein), which is used in the initial screening, the RdRP gene (encodes the RNA-dependent RNA polymerase) used in disease confirmation, and the $\mathrm{N}$ gene (encodes the $\mathrm{N}$ protein) have been used for an additional confirmatory trial (Gupta et al. 2020). Some genomes used to identify SARS-CoV-2 variations 


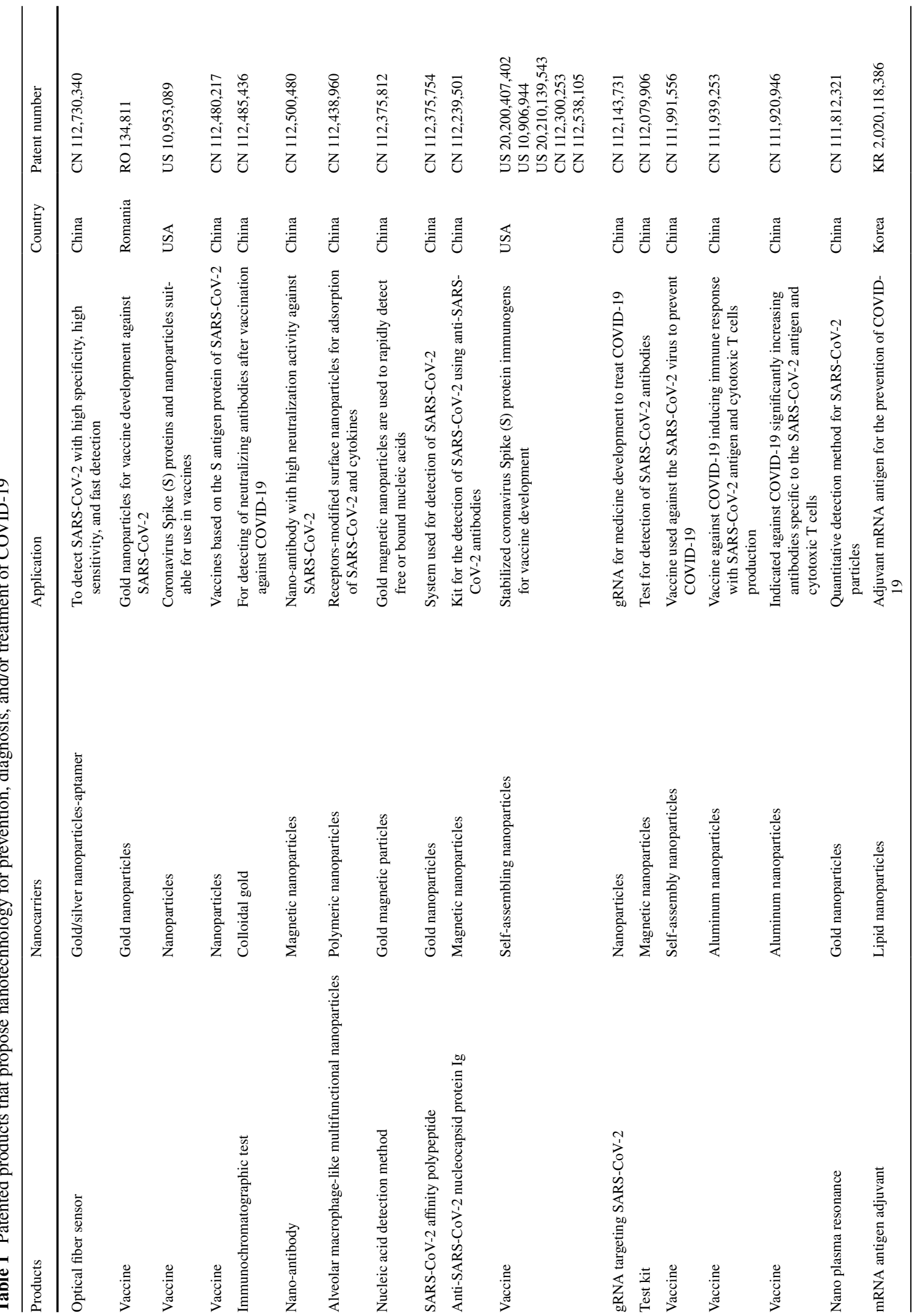




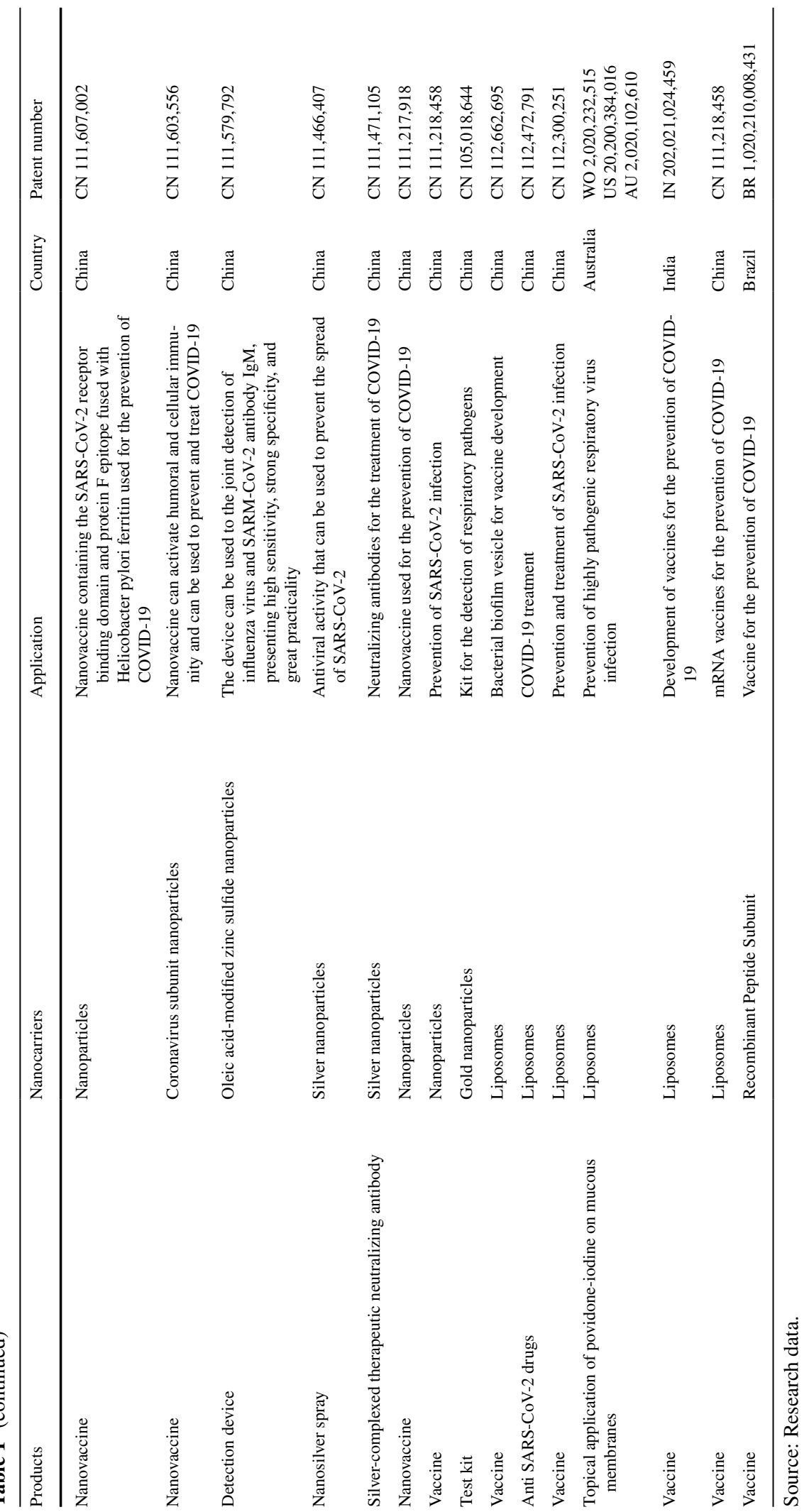


include the L, S, O, V, and G clade with the GH and GR subclade (Yang 2021).

Another widely used method is the immunological, which does not detect the presence of the virus but detects the presence of antibodies produced by the patient's immune system after contact with the virus. This test is not recommended at the onset of symptoms because antibody production has not yet peaked. More specifically, this test detects IgM and IgG antibodies in the patients' blood samples. An advantage is that it can be performed using several techniques, including enzyme-linked immunosorbent assay (ELISA), immunochromatographic assay, and chemiluminescent immunoassay. In addition, this method is widely used due to its low financial cost and quick result (Udugama et al. 2020; Shih et al. 2020).

As can be observed, the scope of diagnosis for COVID-19 is already relatively consistent. Unfortunately, this is not the case when it comes to treatment for this disease. After more than a year of pandemic, there is still no treatment with proven efficacy and safety for SARS-CoV-2. This is one of the most significant impasses to significantly reduce the number of deaths from this virus (Kostarelos 2020). The simplest and quickest way to establish a drug for the treatment of COVID-19 is from drug repurposing, which consists of giving new uses to drugs already approved for other diseases (Kabir et al. 2021).

From this strategy, several molecules already approved are being tested for possible treatment against COVID-19, including chloroquine, hydroxychloroquine, lopinavir, ritonavir, ivermectin, remdesivir, and favipiravir (Shih et al. 2020). Among these, some drugs stand out. Chloroquine and hydroxychloroquine are anti-malarial drugs that, despite being studied for the treatment of COVID-19, have a predisposition for the development of cardiotoxicity (Mehra et al. 2020). Since remdesivir is an antiviral previously indicated for treating the Ebola virus, this drug has shown some promising results in clinical tests, but it has not yet been approved for SARS-CoV-2 (Shih et al. 2020).

In addition to these drugs, several others are being tested using in silico tools, which allow the testing of thousands of molecules quickly and financially acceptable (Zhang et al. 2021a). However, despite all these efforts, there is still no drug for the treatment of COVID-19 that the WHO approves.
Application of nanotechnology in the diagnosis of COVID-19

Although the field of COVID-19 testing is solidified, nanotechnology can allow the development of new techniques or improve existing ones. Thus, the focus of researchers in this area is to decrease the time of diagnosis, increase reliability, sensitivity, and other analytical characteristics. Table 2 shows some products developed with nanotechnology to assist in diagnosing COVID-19.

Aiming at such objectives, Hashemi et al. (Hashemi et al. 2021) developed a detection kit based on a nanobiosensor complex (Fig. 6B) that mixes, among other compounds, graphene oxide, and gold nanostars. This nanosystem can identify a different range of pathogens from any aqueous biological sample from the patient due to the interaction with active functional groups of glycoproteins specific to each virus. In addition, this method can detect SARSCoV-2 in just 1 min and has, compared to the gold standard RT-PCR, sensitivity and error rate of $95 \%$ and 5\%, respectively. Graphene has gained prominence for presenting as a unique property a large surface area, easy functionalization, chemical stability, high electronic conductivity, and among other properties, which call attention to the development of sensors to detect biological and non-biological species (Cheng and Ou 2019). Graphene associated with gold nanoparticles allows fast and ultra-sensitive detection (Hashemi et al. 2021). The device developed by Hashemi et al. (Hashemi et al. 2021) is based on electrochemical detection through a confined surface mechanism through an adsorption process which allows the detection of pathogens in aquatic biological media.

Another approach was taken by Liu et al. (Liu et al. 2020a), who developed a rapid test role based on chemiluminescent nanozymes. The material core comprises Co-Fe@hemin-peroxidase nanozyme (Fig. 6A), which catalyzes and amplifies the reaction signal on the outside of the paper with the Spike protein antigen SARS-CoV-2. This role has specificity for the COVID-19 virus and can deliver results in just $16 \mathrm{~min}$. The nanozyme is a nanomaterial that has an intrinsic enzyme mimicking activity. Therefore, the Co-Fe@hemin-peroxidase nanozyme viral detection mechanism is based on the chromogenic reaction catalyzed by the Co-Fe@hemin-peroxidase nanozyme, 
thus acting as enzymatic biosensors. Thus, the nanozyme developed by Liu et al. (Liu et al. 2020a) combined the chemiluminescence of the nanozyme with the high sensitivity of chemiluminescence and high specificity of the immunoassay in developing a rapid antigen detection test for early screening for SARS-CoV-2 infections.

Huang et al. (Huang et al. 2021) developed a lowcost method that detects and quantifies the new coronavirus in just a 15 -min step. This new technique is based on a nanoplasmonic sensor chip coupled with titration plates' microwells. Thus, the antigen-antibody connection between the virus and the chip can be read through spectroscopy. Therefore, this method may be suitable for diagnosing COVID-19 due to its low cost, rapid diagnosis, high specificity, and sensitivity. The nanoplasmonic sensor chip proved advantageous for detecting the entire SARS-CoV-2 virus in a time $<15$ min and low cost.

Another application widely used by large industries in diagnosing COVID-19 is the use of gold nanoparticles (AuNP). This nanosystem allows the test's sensitivity to increasing and the response time to decrease, based on the connection between the nanoparticle and biological compounds (Draz and
Shafiee 2018). For this reason, Canadian researchers have proposed a rapid lateral flow detection kit that can give the result in 5 to $15 \mathrm{~min}$ due to its composition of gold nanoparticles. Similarly, UK researchers have developed another type of rapid detection kit using AuNP that detects IgG and IgM antibodies. This test can present the diagnosis in just $10 \mathrm{~min}$ and has an accuracy of $97.8 \%(\operatorname{IgM})$ and 99.6\% (IgG) (Nanotechnology Products Database 2020).

The development of several Point of Care devices for diagnosing COVID-19 allows evaluating the transmission of SARS-CoV-2 in the community, even in asymptomatic cases, through fast, cheap, and reliable methods. Nanotechnology-based devices have provided these characteristics to COVID-19 rapid diagnostic tests. One of the advantages of nanotechnological products is that the devices are highly selective, not requiring sample treatment for RNA isolation, which is the case for the use of aptamers, for example, that can be used in different technologies. The conjugation of aptamer and AuNP makes the virus protein bind to the formed complex, thus allowing the diagnosis of COVID-19 (Rao 2021).

Table 2 Nanocarriers are used in products for the diagnosis of COVID-19

\begin{tabular}{|c|c|c|c|c|}
\hline Product & Nanocarrier & Applications & Manufacturer & Country \\
\hline ROS detector & Carbon nanotube & $\begin{array}{l}\text { Software that includes an electrochemical ROS/ } \\
\mathrm{H} 2 \mathrm{O} 2 \text { system, providing a flexible and direct } \\
\text { way, quickly and accurately as an in vitro } \\
\text { diagnostic device }\end{array}$ & Nano Hesgar Sazan Salamat Arya & Iran \\
\hline Detection kit & Gold nanoparticles & $\begin{array}{l}\text { Reagents with gold nanoparticles with the ability } \\
\text { to maximize the sensitivity and reliability of } \\
\text { COVID-19 rapid tests }\end{array}$ & NanoComposix & USA \\
\hline Detection kit & Gold nanoparticles & $\begin{array}{l}\text { Test for primary and secondary diagnosis of } \\
\text { COVID-19, with an IgM detection accuracy } \\
\text { of } 97.8 \% \text { and an IgG detection of } 99.6 \% \text { with } \\
\text { results within } 10 \mathrm{~min}\end{array}$ & SureScreen Diagnostics Ltd & UK \\
\hline Detection kit & Gold nanoparticles & $\begin{array}{l}\text { Easy to use tests can be used at home, in the } \\
\text { community, or at the clinic to detect the virus } \\
\text { in } 10 \mathrm{~min}\end{array}$ & Mologic Ltd & UK \\
\hline Sample kit & - & $\begin{array}{l}\text { Medical sample collection device facilitates } \\
\text { more accessible testing for viral infections such } \\
\text { as COVID-19 }\end{array}$ & Lucence Diagnostics Pte Ltd & Singapore \\
\hline Detection kit & Gold nanoparticles & $\begin{array}{l}\text { Test based on RT-LAMP with results similar to } \\
\text { those presented by the RT-PCR test and with a } \\
\text { time of about } 30 \text { min. RT-LAMP has sensitiv- } \\
\text { ity and specificity }\end{array}$ & $\begin{array}{l}\text { Sri Lanka Institute of Nanotech- } \\
\text { nology (SLINTEC) }\end{array}$ & Sri Lanka \\
\hline
\end{tabular}

Source: (Nanotechnology Products Database 2020). 
Fig. 6 Nanosystems are used to increase the sensitivity of biosensors. (A) Co-Fe@ hemin-peroxidase nanozyme; (B) Nanobiosensor composed of graphene oxide and gold nanostars. Source: Created with BioRender.com

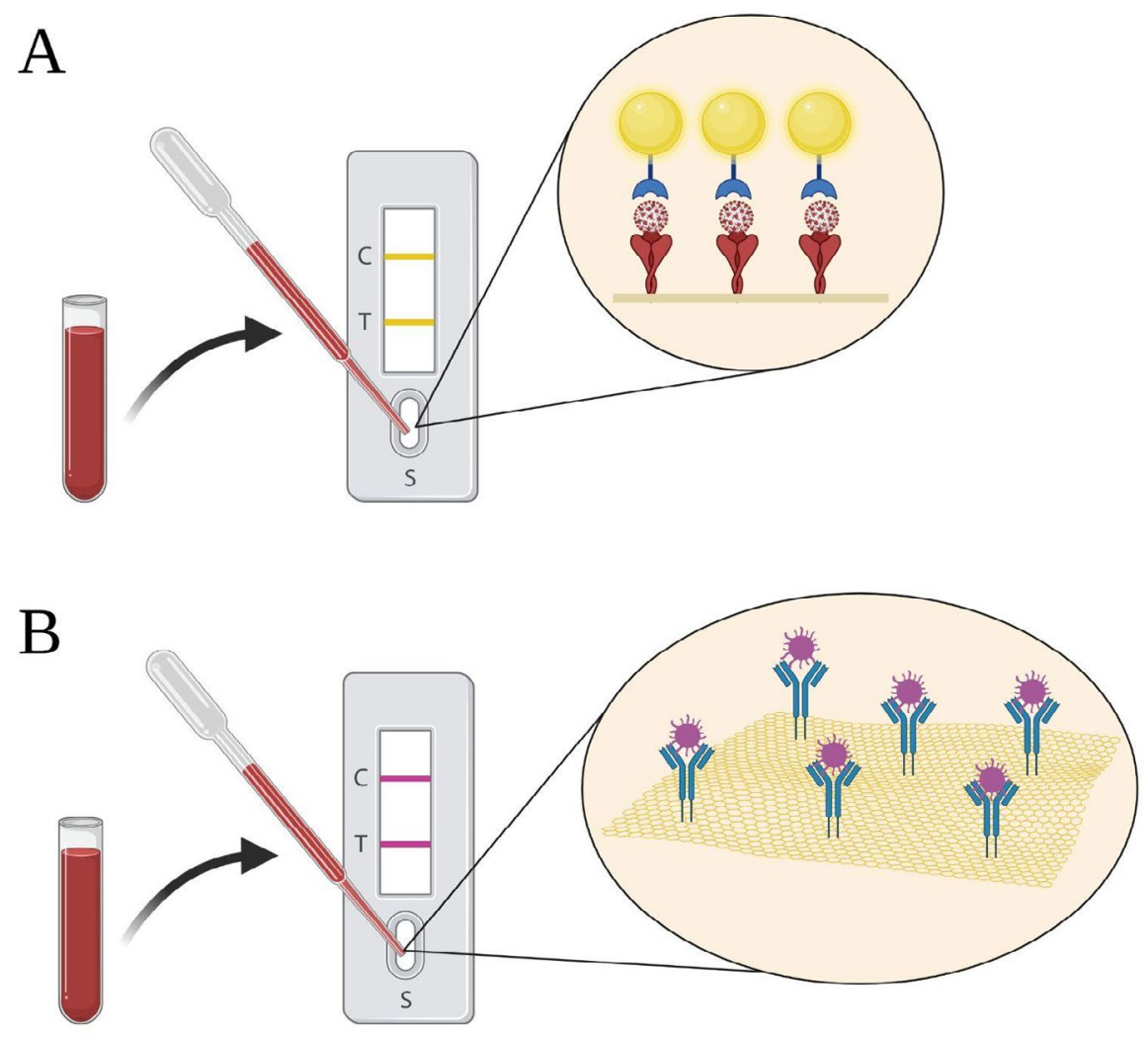

Still, researchers from the USA manufactured a rapid detection kit that uses a BioReady gold reagent composed of gold nanoparticles in the same segment. This test allows the result in 10 to 15 min after applying a drop of patient blood and 2 to 3 drops of the reagent (Nanotechnology Products Database 2020).

Vaccine production in the prevention of COVID-19: contribution of nanotechnology

As a consequence of COVID-19 increasing the number of cases, the world has turned to the development of vaccines, which is hoped to prevent and reduce cases and deaths by COVID-19 (The Lancet Microbe 2021; Wise Xxxx). The urgency for advanced therapeutic choices has led several laboratories and industries to invest in research that focused on developing and releasing an effective vaccine for the most diverse mutations of the SARS-CoV-2 virus (Wise 2021; Forni and Mantovani 2021; Liu et al. 2020b; Yan et al. 2021).

The introduction of nanotechnology has enabled innovative vaccines that carry genetic material from the virus (Cavalcanti and Nogueira 2020). The identification of targets to interrupt the pathogenesis of COVID-19 has gained prominence. From the discovery of the viral protease (3CLpro and PLpro), the protease produced by the host cells (TMPRSS2), the RNA polymerase (RdRp), and the interaction site of viral protein $S$ with the host cell ACE2 receptor has been significant target for vaccine development (Liu et al. 2020b; Choudhary et al. 2021; Uzunian 2020). The most common strategy for most vaccine candidates is related to the induction of neutralizing antibodies against viral S protein, thereby avoiding ACE2-mediated host uptake (Cavalcanti and Nogueira 2020; Chauhan et al. 2020; Dai and Gao 2021; Kyriakidis et al. 2021; Mehta et al. 2020).

The main advantage of using nanotechnology for the development of vaccines against COVID19 is the possibility of carrying the nanosystems to a wide range of antigenic fractions, protecting the native structure of the antigen, and improving the delivery and presentation of the antigens to the presenting cells of antigen (Yang 2021; Pati et al. 
2224; Shin et al. 2020). Additionally, nanosystems are well tolerated in biological systems and can be administered orally, intranasally, subcutaneously, and intramuscular injections. Depending on the administration choice, nanosystems can overcome tissue barriers and direct to target sites (Cavalcanti and Nogueira 2020; Chauhan et al. 2020; Cavalcanti et al. 2020; Germain et al. 2020).

Another advantage of vaccines produced with nanotechnology is the immune response produced. According to the study by Walls et al. (Walls et al. 2020), nanoparticle vaccines exhibit 60 SARS-CoV-2 spike receptor-binding domains (RBD), in addition to being highly immunogenic and inducing the production of 10 times more neutralizing anti-corpora than pre-fusion stabilized spike. Also, antibodies produced by nanoparticle vaccines target multiple distinct epitopes. This makes them not easily susceptible to mutations, exhibiting a lower neutralizing bond than convalescent human sera, thereby reducing the risk of disease's increased respiratory rate associated with the vaccine. Furthermore, the coexposure of several antigens on the same nanoparticles can improve the amplitude of the immune responses induced by the vaccine. Table 3 shows some vaccines that are being developed using nanotechnology.

The approval of two mRNA-based vaccines developed using lipid nanoparticles (LNPs) emerges as a milestone in history, as the first vaccines with these technologies have received authorization for the clinical therapy of COVID-19 by the US FDA (Germain et al. 2020; Khurana et al. 2021). The role of nanotechnology was important, as it accelerated the development of vaccines invented by Moderna and Pfizer/BioNTech, which are currently in phase 4 (Table 1). The primary data for Moderna and Pfizer/BioNTech vaccines revealed an efficacy of $94.5 \%$ and $95 \%$, respectively, against SARS-CoV-2, showing a high efficacy of both vaccines. The difference between the two is related to the genetic material: Moderna (mRNA-1273) uses stabilized mRNA from viral spike protein, while BNT162b2 from Pfizer/BioNTech uses nucleoside-modified RNA (modRNA) from SARS-CoV-2 (Dai and Gao 2021; Polack et al. 2020; Walsh et al. 2020a, 2020b; Zhang et al. 2020b).

Still showing the effectiveness of BNT162b1, Sahin et al. (Sahin et al. 2020) published a study proving that the Pfizer/BioNTech vaccine can induce the production of human antibodies and TH1 cell responses. The authors show that in the two doses of $1-50 \mu \mathrm{g}$ of BNT162b1 in healthy adults (18 to 55 years), CD $4+$ and $\mathrm{CD} 8+\mathrm{T}$ cells and strong antibody responses were produced concentrations of $\mathrm{IgG}$ binding to the RBD of the SARS-CoV-2 virus spike protein. These results are essential, as they show that these mRNA vaccines can both produce an antibody response and $\mathrm{CD} 4+\mathrm{T}$ cells and produce $\mathrm{CD} 8+\mathrm{T}$ cells that play a key role in eradicating the virus (Shin et al. 2020; Han et al. 2021). Figure 7 shows the mechanism of action of these vaccines produced with mRNA.

Vaccines using the SARS-CoV-2 protein subunit have also been gaining prominence for enabling the initiation of the protective immune response when administered with molecular adjuvants for increased immunogenicity (Shin et al. 2020; Kanno et al. 2021). The SARS-CoV-2 subunits used in vaccine production are full-length protein $\mathrm{S}$ formulations or $\mathrm{S} 1 / \mathrm{S} 2$ subunits with adjuvants. Novavax is one of the protein subunit vaccines in phase 3 , using Novavax recombinant nanoparticles and the Matrix-MTM adjuvant. NVX-CoV2373 presented a phase 3 study with an efficiency of $89.3 \%$ (Shin et al. 2020; Han et al. 2021; Callaway and Mallapaty 2021). Also, Keech et al. (Keech et al. 2020) evidenced in their study that Novavax's NVX-CoV2373 was safe when administered to healthy adults aged 18 to 59 years, using a two-dose regimen of $5 \mu \mathrm{g}$ and $25 \mu \mathrm{g}$ of the vaccine plus the adjuvant Matrix-MTM. The results showed that the vaccine could induce high immune responses in the production of neutralizing antibody levels that are closely correlated with the anti-spike IgG antibody.

Like Novavax, the Walter Reed Army Institute of Research has been developing liposomes containing SARS-CoV-2 subunit proteins called $\mathrm{SpFN}$, which is in phase 1 . The technology is based on the use of spike ferritin nanoparticles, which allows the repetitive and orderly presentation of the spike protein to the immune system, thereby inducing highly potent and broad neutralizing antibody responses against SARSCoV-2 (Yan et al. 2021; Powell et al. 2020; Nel and Miller 2021). According to the study by Powell et al. (Powell et al. 2020), spike-functionalized ferritin nanoparticles trigger neutralizing 
Table 3 Vaccine candidates for the treatment of COVID-19 using nanotechnology

\begin{tabular}{|c|c|c|c|c|c|}
\hline Platform & Nanotechnology & Developer & Vaccine name & Clinical status & Trial registration No \\
\hline Protein subunit & Nanoparticles & Novavax & NVX-CoV2373 & Phase 3 & $\begin{array}{l}\text { Phase } 1 / 2 \text { : } \\
\text { NCT04368988 } \\
\text { Phase 2: } \\
\text { NCT04533399 } \\
\text { Phase 3: } \\
\text { NCT04611802 } \\
\text { EUCTR2020-004,123-16-GB } \\
\text { NCT04583995 }\end{array}$ \\
\hline Protein subunit & Ferritin nanoparticle & $\begin{array}{l}\text { Walter Reed Army Institute of } \\
\text { Research (WRAIR) }\end{array}$ & SpFN & Phase 1 & $\begin{array}{l}\text { Phase 1: } \\
\text { NCT04784767 }\end{array}$ \\
\hline mRNA & Lipid nanoparticles & Moderna & $\begin{array}{l}\text { mRNA-1273 } \\
\text { mRNA-1283 }\end{array}$ & Phase 4 & $\begin{array}{l}\text { Phase 1: } \\
\text { NCT04283461 } \\
\text { NCT04813796 } \\
\text { Phase 1/2: } \\
\text { NCT04677660 } \\
\text { NCT04712110 } \\
\text { Phase 2: } \\
\text { NCT04405076 } \\
\text { NCT04761822 } \\
\text { Phase 2/3: } \\
\text { NCT04649151 } \\
\text { NCT04796896 } \\
\text { Phase 3: } \\
\text { NCT04470427 } \\
\text { NCT04811664 } \\
\text { NCT04805125 } \\
\text { NCT04806113 } \\
\text { Phase 4: } \\
\text { NCT04760132 } \\
\text { NCT04792567 }\end{array}$ \\
\hline mRNA & Lipid nanoparticles & $\begin{array}{l}\text { Pfizer/BioNTech + Fosun } \\
\text { Pharma }\end{array}$ & BNT162b2 & Phase 4 & $\begin{array}{l}\text { Phase 1: } \\
\text { NCT04523571 } \\
\text { ChiCTR2000034825 } \\
\text { NCT04816643 } \\
\text { Phase 1/2: } \\
\text { NCT04588480 } \\
\text { NCT04380701 } \\
\text { NCT04537949 } \\
\text { EUCTR2020-003,267-26-DE } \\
\text { Phase 2: } \\
\text { NCT04649021 } \\
\text { NCT04761822 } \\
\text { Phase 2/3: } \\
\text { NCT04754594 } \\
\text { Phase 3: } \\
\text { NCT04368728 } \\
\text { NCT04713553 } \\
\text { NCT04800133 } \\
\text { NCT04805125 } \\
\text { NCT04816669 } \\
\text { Phase 4: } \\
\text { NCT04760132 } \\
\text { EUCTR2021-000,412-28-BE } \\
\text { EUCTR2021-000,412-28-BE } \\
\text { NCT04780659 } \\
\text { NCT04775069 }\end{array}$ \\
\hline mRNA & Lipid nanoparticles & Imperial College London & LNP-nCoVsaRNA & Phase 1 & $\begin{array}{l}\text { Phase 1: } \\
\text { ISRCTN17072692 }\end{array}$ \\
\hline RNA & Lipid nanoparticles & $\begin{array}{l}\text { Academy of Military Science } \\
\text { (AMS), Walvax Biotechnol- } \\
\text { ogy and Suzhou Abogen } \\
\text { Biosciences }\end{array}$ & $\mathrm{ARCoV}$ & Phase 2 & $\begin{array}{l}\text { Phase 1: } \\
\text { ChiCTR2000034112 } \\
\text { ChiCTR2000039212 } \\
\text { Phase 2: } \\
\text { ChiCTR2100041855 }\end{array}$ \\
\hline Virus like particle & - & Medicago Inc & $\begin{array}{l}\text { Coronavirus-like particle } \\
\text { COVID-19 (CoVLP) }\end{array}$ & Phase $2 / 3$ & $\begin{array}{l}\text { Phase 1: } \\
\text { NCT04450004 } \\
\text { Phase 2: } \\
\text { NCT04662697 } \\
\text { Phase 2/3: } \\
\text { NCT04636697 }\end{array}$ \\
\hline
\end{tabular}


Table 3 (continued)

\begin{tabular}{|c|c|c|c|c|c|}
\hline Platform & Nanotechnology & Developer & Vaccine name & Clinical status & Trial registration No \\
\hline DNA & Proteo-lipid vehicle & Entos Pharmaceuticals Inc & Covigenix VAX-001 & Phase 1 & $\begin{array}{l}\text { Phase 1: } \\
\text { NCT04591184 }\end{array}$ \\
\hline mRNA & Lipid nanoparticles & GlaxoSmithKline & CoV2 SAM (LNP) & Phase 1 & $\begin{array}{l}\text { Phase 1: } \\
\text { NCT04758962 }\end{array}$ \\
\hline mRNA & Lipid nanoparticles & $\begin{array}{l}\text { Moderna + National Institute } \\
\text { of Allergy and Infectious } \\
\text { Diseases (NIAID) }\end{array}$ & mRNA-1273.351 & Phase 1 & $\begin{array}{l}\text { Phase 1: } \\
\text { NCT04785144 }\end{array}$ \\
\hline Virus-like particle & - & $\begin{array}{l}\text { The Scientific and Technological } \\
\text { Research Council of Turkey }\end{array}$ & SARS-CoV-2 VLP & Phase 1 & $\begin{array}{l}\text { Phase 1: } \\
\text { NCT04818281 }\end{array}$ \\
\hline
\end{tabular}

Source: (Yan et al. 2021).

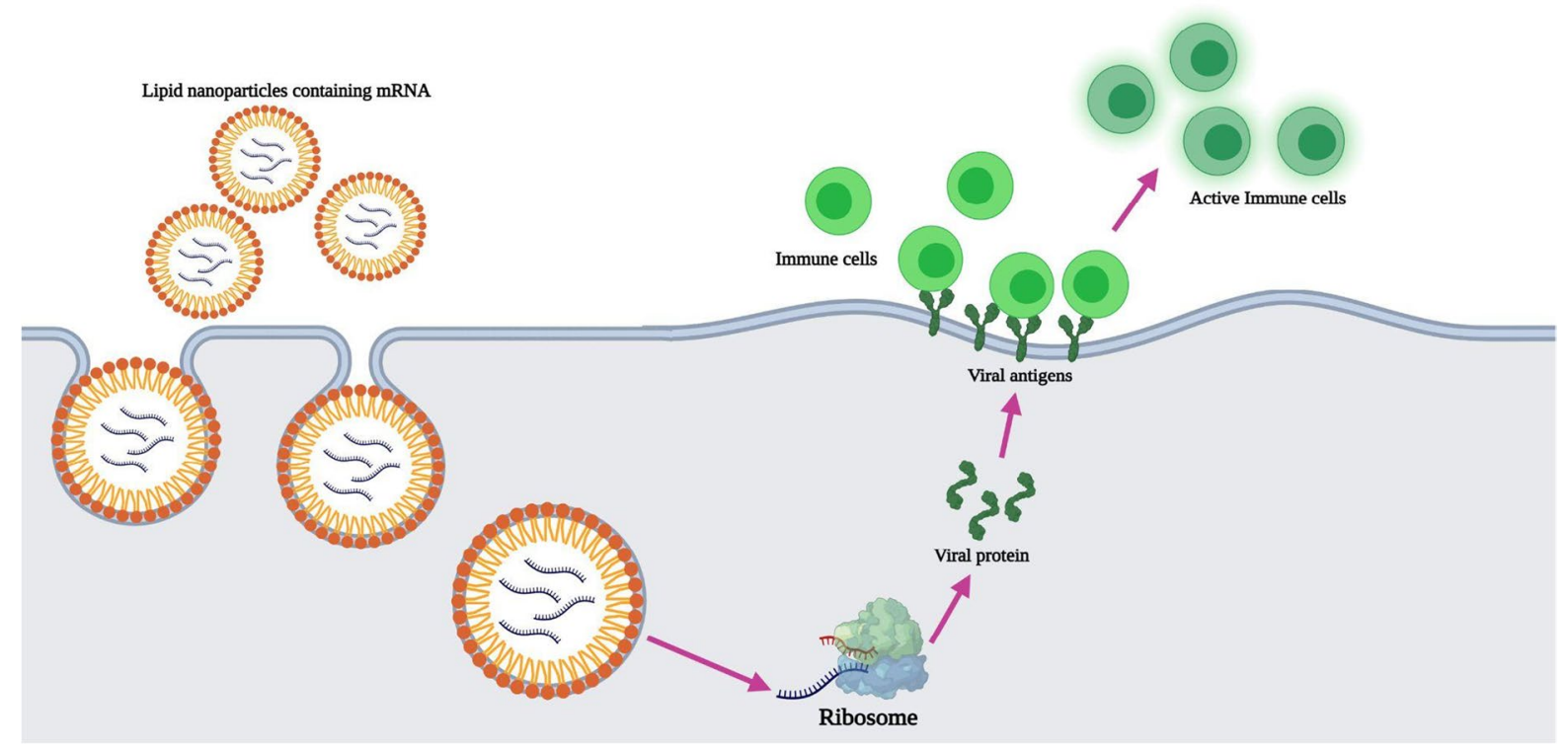

Fig. 7 Mechanism of action of vaccines containing mRNA encapsulated into lipid nanoparticles. Source: Created with BioRender. com

antibody responses against SARS-CoV-2 with only a single immunization in their research with mice compared to immunization with the spike RBD monomer.

Saunders et al. (Saunders et al. 2021) developed a vaccine for COVID-19 using self-assembling protein nanoparticles of 24 Helicobacter pylori ferritin subunits expressing RBD of SARS-CoV-2. The vaccine is administered using the $3 \mathrm{M}-052 /$ Alum adjuvant. The authors observed that this vaccine induces a cross-neutralizing antibody response against batCoVs, SARS-CoV-1, SARSCoV-2, and variants B.1.1.7, P.1, and B.1.351 of the SARS-CoV-2 virus.
Subunit vaccines also allow them to take the form of protein nanoparticles or virus-like particles (VLPs) (Nooraei et al. 2021). The vaccine in production by Medicago Inc. is produced from VLPs, featuring a recombinant spike glycoprotein expressed as SARS-CoV-2-like particles and is administered together with an adjuvant produced by GlaxoSmithKline (GSK). Currently, the vaccine is in phase 2/3 (Forni and Mantovani 2021; Kyriakidis et al. 2021; Galdiero et al. 2021; Kumar et al. 2021). The Scientific and Technological Research Council of Turkey is also developing VLP vaccines. However, it is in phase 1 (Yan et al. 2021). 
Nanocarriers in the treatment of COVID-19

As already discussed, one of the biggest challenges in overcoming the COVID-19 crisis is the lack of drugs to treat the disease. Moreover, in response to this problem, the repurposing of already known drugs is being studied. Thus, the association of these drugs with nanocarriers can be an essential strategy for success in this area.

Nanocarriers are a system at the nanoscale into which materials are encapsulated. These nanosystems allow a controlled release of encapsulated drugs, increased bioavailability, and targeted specific cells, among other particularities (Reinholz et al. 2018).

Aiming at these advantages, Pindiprolu et al. (Pindiprolu et al. 2020) proposed using Salinomycin lipid nanoparticles to treat COVID-19 by the pulmonary route. Salinomycin has antibacterial, antifungal, antiparasitic, antitumor, and antiviral properties, but it has very low water solubility (Zhang et al. 2012). For this reason, its encapsulation into lipid nanoparticles allows an increase in solubility for faster and more efficient absorption and, consequently, enables the inhibition of SARS-CoV-2 entry and replication in cells (Pindiprolu et al. 2020).

In addition, the pulmonary route (Fig. 8), which is a non-invasive route, has been widely used by scientists in recent years and can provide enormous advantages in treating COVID-19. This route allows the targeting of drugs directly to the target cells located in the respiratory system, decreasing the first-pass metabolism and, thus, reducing side effects and increasing the bioavailability of the molecule (Douafer et al. 2020).

Using the same route of administration, researchers from Cyprus developed a chitosan nanoparticle for application in aerosol called Novochizol. This nanosystem allows the encapsulation of different drugs for the respiratory system to allow an efficient treatment for patients with COVID-19. In addition to the benefits of using this route, these nanoparticles have the property of controlled drug release, maintaining a plasma concentration with therapeutic action within $3 \mathrm{~h}$ after Novochizol administration (Nanotechnology Products Database 2020; Novochizol. 2020).

Another nanocarrier that uses this same route of administration was developed by researchers in the USA named NanoBio® Protect. This product is an antiseptic solution for intranasal use consisting of nanodroplets containing benzalkonium chloride (BZK). These nanoparticles are attracted to electrokinetic germs and present BZK, causing the death of microorganisms by contact. Thus, this product allows further infection prevention by the SARS-CoV-2 virus (Nanotechnology Products Database 2020; Available. 2020).

In search of a more innovative treatment, Refaat et al. (Refaat et al. 2021) developed a liposomal formulation to increase the antiviral property of propolis. Propolis is a resin produced by bees from the sap

\section{Nanomicelles $\begin{gathered}\text { Lipid } \\ \text { nanoparticles }\end{gathered}$ Nanoparticles}
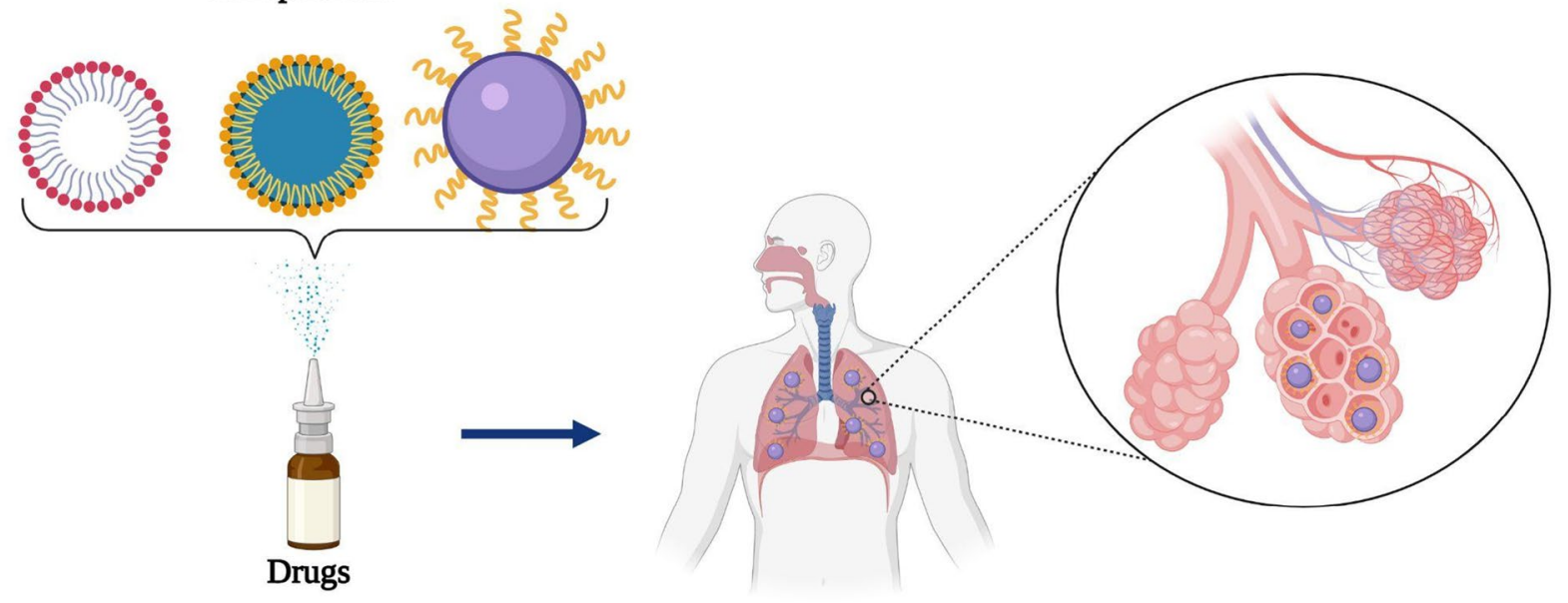

Fig. 8 Nanocarriers are administered via the pulmonary route to deliver drugs directly to the lung. Source: Created with BioRender. com 
Fig. 9 Nanoparticles inserted in individual and collective protection equipment against COVID-19.

(A) Graphene in protective masks; (B) Air conditioning containing nanotechnology for cleaning the environment; (C) Solution for surface cleaning containing nanoparticles. Source: Created with BioRender.com

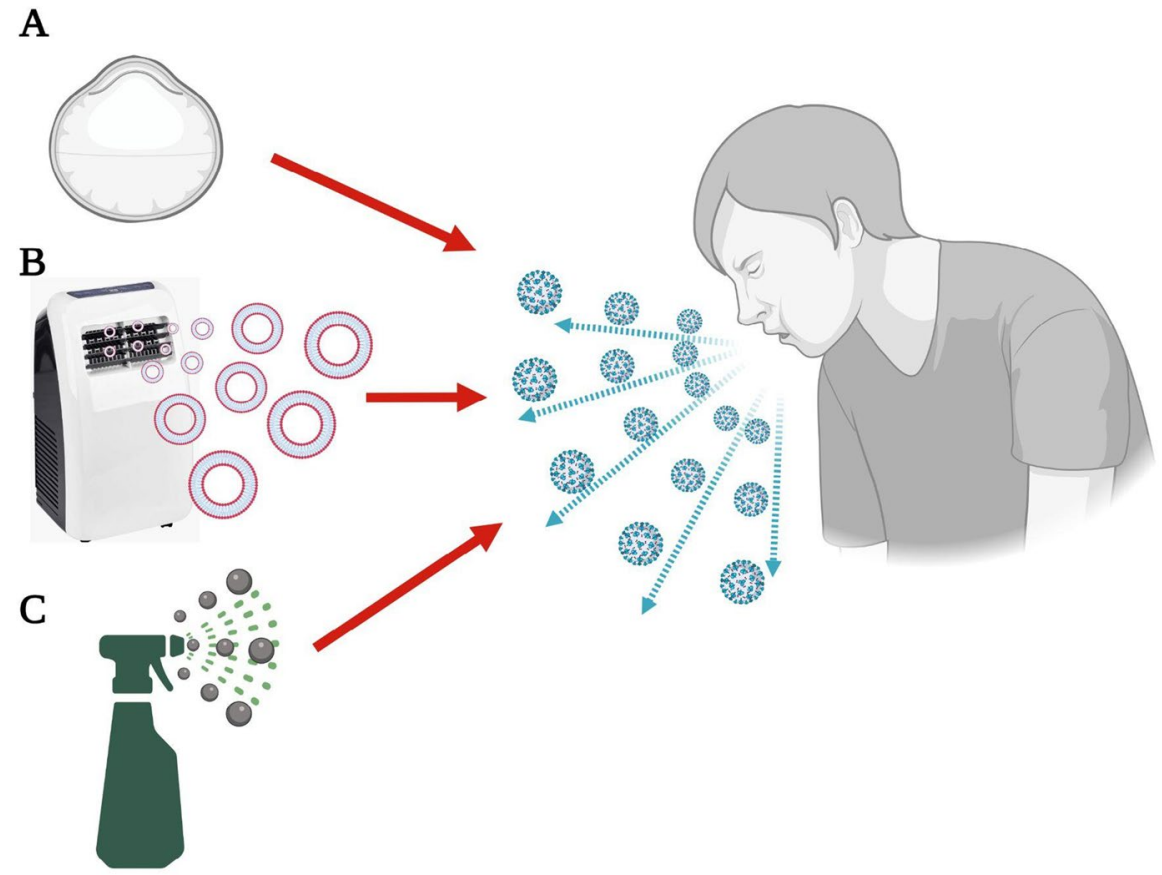

of trees, rich in numerous compounds with various pharmacological activities, including antibacterial, immunomodulatory, anti-inflammatory, and antiviral (Refaat et al. 2021; Simone-Finstrom and Spivak 2010). Given this, these encapsulated propolis liposomes have shown encouraging results and viral inhibition parameters similar to potent antivirals such as Remdesivir (Refaat et al. 2021).

Similarly, Valizadeh et al. (Valizadeh et al. 2020) developed nanomicelles, encapsulating curcumin to evaluate the effects of this nanosystem on modulation or suppression of cytokines. The over-activation of the inflammatory system caused by SARS-CoV-2 is the leading cause of lung tissue damage and, consequently, of the deaths caused by COVID-19. In contrast, curcumin is the active substance in Curcuma longa and is widely used due to its medicinal properties as an antioxidant, anti-tumor, and antiinflammatory. Therefore, the association of curcumin in nanomicelles allowed the delivery of this molecule efficiently, and it was possible to observe an attenuating decrease in the expression of IL1 $\beta$ and IL-6.

US researchers have developed NanoBio ${ }^{\circledR}$ Protect, which is based on the inclusion of the antiseptic benzalkonium chloride (BZK) on the surface of nanodrops. These nanoparticles are attracted to the microorganisms by electrokinetic charge, and the presence of BZK causes the microorganism to be killed after contact. These nanodrops persist in the hair for $4 \mathrm{~h}$ or more, showing long-lasting effectiveness. In addition, these nanodrops also significantly moisturize the skin, thereby preventing dryness and cracking after application to the skin around the nose (Nanotechnology Products Database 2020).

Personal and collective protective equipment against COVID-19

Another crucial aspect for controlling COVID-19 is the protection provided by personal protective equipment (PPE) and collective protection equipment (CPE). Implementing nanosystems in these devices enables antiviral properties and increases particle filtration capacity (Palmieri et al. 2021). Figure 9 shows some protective equipment that is being developed using nanotechnology.

Several companies have invested in developing products using nanotechnology as a basis for the supply of hygiene products that have more extended durability in action against pathogens and the development of self-cleaning masks and purifiers that can purify work environments and make them free of pathogens. Table 4 shows the most diverse products 
Table 4 Individual and collective protective equipment based on nanotechnology for COVID-19

\begin{tabular}{|c|c|c|c|c|}
\hline Product & Nanocarrier & Applications & Manufacturer & Country \\
\hline Respiratory mask & Silver nanoparticles & $\begin{array}{l}\text { Mask used to protect against } \\
\text { infection by COVID-19, } \\
\text { with antiviral efficacy of } \\
\text { up to } 90 \%\end{array}$ & SEN WORLD & Czech Republic \\
\hline Respiratory mask & Nanofibers & $\begin{array}{l}\text { Mask used to protect against } \\
\text { infection by COVID-19, } \\
\text { presents } \geq 99.9 \% \text { of the } \\
\text { capture of particles in the } \\
\text { membrane }\end{array}$ & Pardam Nano4fibers & Czech Republic \\
\hline Respiratory mask & Silver nanoparticles & $\begin{array}{l}\text { Respiratory protection has } \\
\text { a } 99.9 \% \text { action capacity } \\
\text { against bacteria after } 60 \\
\text { washes }\end{array}$ & $\begin{array}{l}\text { Dony Garment Company } \\
\text { Limited }\end{array}$ & Vietnam \\
\hline Respiratory mask & $\begin{array}{l}\text { Silver nanoparticles and } \\
\text { graphene }\end{array}$ & $\begin{array}{l}\text { Respiratory protection man- } \\
\text { ages to destroy } 99.9 \% \text { of } \\
\text { the SARS-CoV-2 virus }\end{array}$ & NM Material & India \\
\hline Respiratory mask & Graphene & $\begin{array}{l}\text { Respiratory protection } \\
\text { can kill particles of the } \\
\text { SARS-CoV-2 virus, in } \\
\text { addition to other infec- } \\
\text { tious diseases, capable of } \\
\text { killing } 99 \% \text { of viruses and } \\
\text { germs }\end{array}$ & Medicevo Corporation & USA \\
\hline Respiratory mask & $\begin{array}{l}\text { Copper yarn and nanofabric } \\
\text { spandex }\end{array}$ & $\begin{array}{l}\text { Elastic and durable masks } \\
\text { with action against } \\
\text { COVID-19 }\end{array}$ & Gian Ferrente & Thailand \\
\hline Respiratory mask & Graphene & $\begin{array}{l}\text { Washable masks with } \\
\text { graphene antiviral filter, } \\
\text { providing respiratory } \\
\text { protection to the user }\end{array}$ & Flextrapower Inc & USA \\
\hline Respiratory mask & Graphene & $\begin{array}{l}\text { Masks that have the ability } \\
\text { to stop } 99 \% \text { of particles } \\
\text { over } 0.3 \text { microns and } 80 \% \\
\text { of particles less than } 0.3 \\
\text { microns }\end{array}$ & LIGC Applications Ltd & USA \\
\hline Respiratory mask & Graphene & $\begin{array}{l}\text { Respiratory protection in } \\
\text { the prevention of COVID- } \\
19\end{array}$ & Directa Plus PLC & UK \\
\hline Respiratory mask & Copper nanoparticles & $\begin{array}{l}\text { Respiratory protection in } \\
\text { the prevention of COVID- } \\
19\end{array}$ & Promethean Particles Ltd & UK \\
\hline Respiratory mask & Nanofibers & $\begin{array}{l}\text { Respiratory protection in } \\
\text { the prevention of COVID- } \\
19\end{array}$ & $\begin{array}{l}\text { Kim Ii-Doo Research } \\
\text { Institute }\end{array}$ & South Korea \\
\hline Respiratory mask & Molecular nanocoat & $\begin{array}{l}\text { Self-cleaning and sanitizing } \\
\text { surgical mask that kills } \\
99.9 \% \text { of all viruses and } \\
\text { bacteria }\end{array}$ & MVX Prime Ltd & UK \\
\hline Respiratory mask & Nano Biotech & $\begin{array}{l}\text { Respiratory protection } \\
\text { against SARS-CoV-2 with } \\
\text { a complete inactivation } \\
\text { effect of up to } 99 \%\end{array}$ & Wakamono & Vietnam \\
\hline Respiratory mask & Hydrophobic coating & $\begin{array}{l}\text { Respiratory protection } \\
\text { against SARS-CoV-2 }\end{array}$ & Integricote Inc & USA \\
\hline
\end{tabular}


Table 4 (continued)

\begin{tabular}{|c|c|c|c|c|}
\hline Product & Nanocarrier & Applications & Manufacturer & Country \\
\hline Disinfection chamber & - & $\begin{array}{l}\text { Portable ultraviolet light } \\
\text { disinfectant to sanitize } \\
\text { all types of surfaces, act- } \\
\text { ing against bacteria and } \\
\text { viruses }\end{array}$ & Log 9 Materials Pvt. Ltd & India \\
\hline Liquid screen protector & $\begin{array}{l}\text { Silver and titanium dioxide } \\
\text { nanoparticles }\end{array}$ & $\begin{array}{l}\text { Protection of cell phones, } \\
\text { making the cell phone } \\
\text { screen scratch-resistant, } \\
\text { germ-free and water- } \\
\text { repellent }\end{array}$ & Nanofixit Inc & Philippines \\
\hline Coating & - & $\begin{array}{l}\text { Indicated for all types } \\
\text { of fabrics that transmit } \\
\text { superhydrophobicity, non- } \\
\text { toxicity, and breathabil- } \\
\text { ity, forming a protective } \\
\text { barrier under the fabric } \\
\text { surface }\end{array}$ & Curran Biotech & USA \\
\hline Disinfecting spray & - & $\begin{array}{l}\text { Eradicates bacteria from } \\
\text { surfaces and purifies the } \\
\text { air }\end{array}$ & $\begin{array}{l}\text { Sri Lanka Institute of Nano- } \\
\text { technology (SLINTEC) }\end{array}$ & Sri Lanka \\
\hline Air purifier & ShortWaveLight Emitter & $\begin{array}{l}\text { Through ultraviolet light } \\
\text { with germicidal action, } \\
\text { this purifier neutralizes } \\
\text { coronavirus and other } \\
\text { pathogens on surfaces and } \\
\text { in the air }\end{array}$ & NS Nanotech, Inc & USA \\
\hline Screen protector & Copper nanoparticles & $\begin{array}{l}\text { Screen saver that eradicates } \\
\text { viruses and bacteria } \\
\text { in minutes, due to the } \\
\text { antiviral and antibacterial } \\
\text { properties of copper }\end{array}$ & Nanoveu Inc & Australia \\
\hline Disinfectant & $\begin{array}{l}\text { Photocatalytic nanotechnol- } \\
\text { ogy }\end{array}$ & $\begin{array}{l}\text { Protects high-touch surfaces } \\
\text { against bacteria, viruses, } \\
\text { fungi, among others }\end{array}$ & EnvisionSQ & Canada \\
\hline Antiviral ink & $\begin{array}{l}\text { Silver nanoparticles and } \\
\text { graphene }\end{array}$ & $\begin{array}{l}\text { Used to manufacture PPE's } \\
\text { against COVID-19 }\end{array}$ & $\begin{array}{l}\text { ZEN Graphene Solutions } \\
\text { Ltd }\end{array}$ & Canada \\
\hline Disinfectant & Mineral nanocrystals & $\begin{array}{l}\text { It provides self-cleaning } \\
\text { surfaces with the possibil- } \\
\text { ity of using the product on } \\
\text { the door handles, elevator } \\
\text { buttons, and on the back } \\
\text { of the phone }\end{array}$ & Nanotouch Materials, LLC & USA \\
\hline Hand sanitizer & Silver nanoparticles & $\begin{array}{l}\text { Broad-spectrum hand sani- } \\
\text { tizer against microorgan- } \\
\text { isms, without the need for } \\
\text { water or towels }\end{array}$ & Shepros SDN. BHD & Malaysia \\
\hline Air-conditioning cleaner & - & $\begin{array}{l}\text { Clean air filtration system } \\
\text { against SARS-CoV-2 } \\
\text { virus, mold and mildew, } \\
\text { animal hair }\end{array}$ & Mark Antonoff HVAC & USA \\
\hline Air purifier & - & $\begin{array}{l}\text { Captures } 99.5 \% \text { of viruses } \\
\text { and bacteria, with 6-12 air } \\
\text { changes per hour }\end{array}$ & $\begin{array}{l}\text { Turn-Key Environmental } \\
\text { Consultants }\end{array}$ & USA \\
\hline
\end{tabular}


Table 4 (continued)

\begin{tabular}{|c|c|c|c|c|}
\hline Product & Nanocarrier & Applications & Manufacturer & Country \\
\hline Air purifier & - & $\begin{array}{l}\text { Efficiently removes chemi- } \\
\text { cals, pollutants, viruses, } \\
\text { bacteria, and allergens } \\
\text { from the air }\end{array}$ & AAVI Technologies Co & Finland \\
\hline Air purifier & - & $\begin{array}{l}\text { Prevents airborne infec- } \\
\text { tions, as is the case with } \\
\text { COVID-19 }\end{array}$ & TEQOYA & France \\
\hline Air purifier & - & $\begin{array}{l}\text { It works by improving } \\
\text { the performance of } \\
\text { central ventilation as an } \\
\text { additional purification } \\
\text { system, providing constant } \\
\text { nanoscale contamination } \\
\text { control }\end{array}$ & Genano Ltd & Finland \\
\hline
\end{tabular}

Source: (Nanotechnology Products Database 2020).

indicated in the prevention and protection against SARS.CoV-2.

Zhang et al. (Zhang et al. 2021b) developed an exciting method to increase the time of use and useful life of surgical masks using triboelectric nanogenerator technology (TENG). This generator can transform external mechanical energy into electrical energy based on static electricity and triboelectric effect (Fan et al. 2012; Wu et al. 2018). The method developed by Zhang et al. (Zhang et al. 2021b) consists of the discharge of this generated energy using an electrode in the surgical mask, already used and decontaminated. This process allows re-energizing the layers of electrostatic filtering tissues, which generally dissipate this energy in a few hours (Lee and Kim 2020). The authors demonstrated that even after 10 cycles of this method, the filtering efficiency of the masks remained above $95 \%$. Therefore, usage time and useful life can be increased by at least 10 times (Zhang et al. 2021b).

Using the same concepts, Leung and Sun (Leung and Sun 2020) developed and produced 4 new electrostatically charged nanofiber fabrics for filtering particles up to $100 \mathrm{~nm}$ suspended in the air. These tissues were made using polyvinylidene fluoride in electrospinning and were charged electrostatically from a process called corona discharge. Still, in the tissue segment, Almeida et al. (Almeida et al. 2020) produced a biodegradable fabric composed of nanofibers from the cellulose acetate polymer and the surfactant cetylpyridinium bromide, also using the electrospinning technique. This tissue proved to be efficient in the filtration of particles with diameters smaller than $300 \mathrm{~nm}$. Therefore, it could be used for the filtration of SARS-CoV-2.

Different nanoparticles in fabrics used in masks to protect against COVID-19 are being studied and carried out by the medical industry. Among these, silver nanoparticles (AgNP) were considered the most useful disinfectant metal to fight bacteria and viruses due to the release of silver ions by oxidation (Wang et al. 2019). Therefore, researchers in India produced the first graphene mask with silver nanoparticles. This product was developed from the coating of graphene and AgNP on the fibers of polyester fabric, so this technology neutralizes and filters viruses and bacteria with extremely high efficiency. For SARS-CoV-2, the filtration efficiency reached $99.9 \%$, so this mask has exceptionally high protection in preventing COVID-19 (Nanotechnology Products Database 2020; Nanomatrix materials. 2021). Vietnamese researchers developed another product produced using AgNP. The Dony Mask is a 3-layer mask containing AgNP, allowing efficient filtration of viruses and bacteria even after 60 wash cycles (Nanotechnology Products Database 2020).

Still concerning the production of masks, Chinese researchers developed masks that use diamond nanoparticles (ND). These surgical masks contain 3 layers: a hydrophobic outer layer containing ND, an intermediate layer that performs the filtration, and a non-allergenic inner layer for skin contact. 
According to manufacturers, ND allows killing some bacteria and viruses with $99 \%$ and $97.75 \%$ efficiency in up to $1 \mathrm{~min}$ (Nanotechnology Products Database 2020; Patented anti-microbial NanoDiamonds (ND) mask. 2020;).

In addition to this personal protective equipment, several air purifiers and filters are being produced for collective protection. US researchers have developed the ShortWaveLight Purifier, a portable air purifier that emits UVC radiation to neutralize various pathogens, including SARS-CoV-2. Another purifier designed in the USA is the HealthPro Compact Air Purifier, capturing $99.5 \%$ of viruses and bacteria in the environment. EnvisionSQ has developed an air purifier based on photocatalysis. It uses light energy to accelerate chemical reactions with the filtered particles (Nanotechnology Products Database 2020).

\section{Conclusion}

Since the emergence of the SARS-CoV-2 virus, COVID-19, has infected and killed millions of people worldwide and has been regarded as the world's worst public health problem since the Spanish flu in the twentieth century. After a century, technology has advanced exponentially and can be used to save countless lives. In this sense, nanotechnology and nanomedicine play a crucial role against numerous diseases, including COVID-19.

We note the importance of nanotechnology for the treatment, prevention, and protection against SARS-CoV-2. However, despite all significant advances reported in this article, much investment and research are still needed to overcome the pandemic definitively.

Acknowledgements We thank the Biorender website for allowing the construction of the figures.

Funding The first author and Cavalcanti thank the Brazilian National Council for Scientific and Technological Development (CNPq) for the Institutional Scientific Initiation Scholarship Program (PIBIC) and PhD scholarship (CNPq \#141307/20200 ). Magalhães thanks the Coordenação de Aperfeiçoamento de Pessoal de Nível Superior (CAPES) for the Programa Institucional de Internalização (Print) (\#2761/2018) and the Conselho Nacional de Desenvolvimento Científico e Tecnológico $(\mathrm{CNPq})$ for financial support and investigator research grants (\#307968/2019-7). Lira-Nogueira thanks Propesqui
UFPE QualisA (054228/2020-29) and Auxílio Pesquisador (065880/2020-93).

\section{Declarations}

Conflict of interest The authors declare no competing interests.

\section{References}

Almeida DS, Martins LD, Muniz EC, Rudke AP, Squizzato R, Beal A et al (2020) Biodegradable CA/CPB electrospun nanofibers for efficient retention of airborne nanoparticles. Process Saf Environ Prot 144:177-185. https://doi.org/10. 1016/j.psep.2020.07.024

Anselmo AC, Mitragotri S (2019) Nanoparticles in the clinic: an update. Bioengineering \& Translational Medicine 4(3):e10143. https://doi.org/10.1002/btm2.10143

Bhat EA, Khan J, Sajjad N, Ali A, Aldakeel FM, Mateen A et al (2021) SARS-CoV-2: insight in genome structure, pathogenesis and viral receptor binding analysis - an updated review. Int Immunopharmacol 95:107493. https:// doi.org/10.1016/j.intimp.2021.107493

Bobo D, Robinson KJ, Islam J, Thurecht KJ, Corrie SR (2016) Nanoparticle-based medicines: a review of FDA-approved materials and clinical trials to date. Pharm Res 33(10):2373-2387. https://doi.org/10.1007/ s11095-016-1958-5

Callaway E, Mallapaty S (2021) Novavax offers first evidence that COVID vaccines protect people against variants. Nature. Available in: https://www.nature.com/articles/ d41586-021-00268-9. Accessed in: May 12, 2021

Caster JM, Patel AN, Zhang T, Wang A (2016) Investigational nanomedicines in 2016: a review of nanotherapeutics currently undergoing clinical trials. Wiley Interdisciplinary Reviews: Nanomedicine and Nanobiotechnology 9(1):e1416. https://doi.org/10.1002/wnan.1416

Cavalcanti IDL, Nogueira MCBL (2020) Pharmaceutical nanotechnology: which products are been designed against COVID-19? J Nanoparticle Res 22(276). https:// doi.org/10.1007/s11051-020-05010-6

Cavalcanti IDL, Medeiros SMFRS, Macêdo DCS, Cavalcanti IMF, Nogueira MCBL (2020) Nanocarriers in the delivery of hydroxychloroquine to the respiratory system: an alternative to COVID-19. Current Drug Delivery 17 https://doi.org/10.2174/1567201817666200827110445

Chan WCW (2020) Nano research for COVID-19. ACS Nano. https://doi.org/10.1021/acsnano.0c02540

Chauhan G, Madou MJ, Kalra S, Chopra V, Ghosh D, Martinez-Chapa SO (2020) Nanotechnology for COVID-19: therapeutics and vaccine research. ACS Nano 17:77607782. https://doi.org/10.1021/acsnano.0c04006

Cheng R, Ou S (2019) Nanocomposite-based graphene for nanosensor applications. Intechopen. London, United Kingdom

Choudhary J, Dheeman S, Sharma V, Katiyar P, Karn SK, Sarangi MK et al (2021) Insights of severe acute respiratory syndrome coronavirus (SARS-CoV-2) pandemic: 
a current review. Biological Procedures Online 23(5). https://doi.org/10.1186/s12575-020-00141-5

Dai L, Gao GF (2021) Viral targets for vaccines against COVID-19. Nat Rev Immunol 21:73-82. https://doi.org/ 10.1038/s41577-020-00480-0

Dejnirattisai W, Zhou D, Supasa P, Liu C, Mentzer AJ, Ginn HM et al (2021) Antibody evasion by the P.1 strain of SARS-CoV-2. Cell 184(11):2939-2954. https://doi.org/ 10.1016/j.cell.2021.03.055

Douafer H, Andrieu V, Brunel JM (2020) Scope and limitations on aerosol drug delivery for the treatment of infectious respiratory diseases. J Control Release 325:276292. https://doi.org/10.1016/j.jconrel.2020.07.002

Draz MS, Shafiee H (2018) Applications of gold nanoparticles in virus detection. Theranostics 8(7):1985-2017. https://doi.org/10.7150/thno.23856

Fan FR, Tian ZQ, Wang ZL (2012) Flexible triboelectric generator. Nano Energy 1(2):328-334. https://doi.org/ 10.1016/j.nanoen.2012.01.004

Farjadian F, Ghasemi A, Gohari O, Roointan A, Karimi M, Hamblin MR (2019) Nanopharmaceutical and nanomedicines currently on the market: challenges and opportunities. Nanomedicine (london) 14(1):93-126. https:// doi.org/10.2217/nnm-2018-0120

FDA - U.S. Food \& Drug Administration (2020) Search for FDA guidance documents [Internet]. FDA. Available from: http://www.fda.gov/regulatory-information/ search-fda-guidance-documents. Accessed in: June 6, 2021.

Forni G, Mantovani A (2021) COVID-19 vaccines: where we stand and challenges ahead. Cell Death Differ 28:626639. https://doi.org/10.1038/s41418-020-00720-9

Galdiero M, Galdiero M, Folliero V, Zannella C, Filippis A, Mali A et al (2021) SARS-CoV-2 vaccine development: where are we? Eur Rev Med Pharmacol Sci 25:2752-2784

Germain M, Caputo F, Metcalfe S, Tosi G, Spring K, Aslund AKO et al (2020) Delivering the power of nanomedicine to patients today. J Control Release 326:164-171. https:// doi.org/10.1016/j.jconrel.2020.07.007

Gupta R, Sagar P, Priyadarshi N, Kaul S, Sandhir R, Rishi V, Singhal NK (2020) Nanotechnology-based approaches for the detection of SARS-CoV-2. Frontiers in Nanotechnology 2:589832. https://doi.org/10.3389/fnano.2020.589832

Han HJ, Nwagwu C, Anyim O, Ekweremadu C, Kim S (2021) COVID-19 and cancer: from basic mechanisms to vaccine development using nanotechnology. International Immunopharmacology 90 https://doi.org/10.1016/j.intimp.2020. 107247

Hashemi SA, Golab Behbahan NG, Bahrani S, Mousavi SM, Gholami A, Ramakrishna S et al (2021) Ultra-sensitive viral glycoprotein detection NanoSystem toward accurate tracing SARS-CoV-2 in biological/non-biological media. Biosens Bioelectron 171:112731. https://doi.org/10. 1016/j.bios.2020.112731

Huang L, Ding L, Zhou J, Chen S, Chen F, Zhao C et al (2021) One-step rapid quantification of SARS-CoV-2 virus particles via low-cost nanoplasmonic sensors in generic microplate reader and point-of-care device. Biosens Bioelectron 171:112685. https://doi.org/10.1016/j.bios.2020.112685

Kabir ER, Mustafa N, Nausheen N, Sharif Siam MK, Syed EU (2021) Exploring existing drugs: proposing potential compounds in the treatment of COVID-19. Heliyon 7(2):e06284. https://doi.org/10.1016/j.heliyon.2021. $\mathrm{e} 06284$

Kanno AI, Barbosa MMF, Moraes L, Leite LCC (2021) SARSCoV-2 vaccine development and how Brazil is contributing. Genet Mol Biol 44(1):1-15. https://doi.org/10.1590/ 1678-4685-gmb-2020-0320

Keech C, Albert G, Cho I, Robertson A, Reed P, Neal S et al (2020) Phase 1-2 trial of a SARS-CoV-2 recombinant spike protein nanoparticle vaccine. N Engl J Med 383:2320-2332. https://doi.org/10.1056/NEJMoa2026920

Khurana A, Allawadhi P, Khurana I, Allwadhi S, Weiskirchen R, Banothu AK et al (2021) Role of nanotechnology behind the success of mRNA vaccines for COVID-19. Nanotoday 38(101142) https://doi.org/10.1016/j.nantod. 2021.101142

Kostarelos K (2020) Nanoscale nights of COVID-19. Nat Nanotechnol 15(5):343-344. https://doi.org/10.1038/ s41565-020-0687-4

Kumar AU, Kadiresen K, Gan WC, Ling APK (2021) Current updates and research on plant-based vaccines for coronavirus disease 2019. Clinical and Experimental Vaccine Research 10(1):13-23. https://doi.org/10.7774/cevr.2021. 10.1.13

Kyriakidis NC, López-Cortés A, González EV, Grimaldos AB, Prado EO (2021) SARS-CoV-2 vaccines strategies: a comprehensive review of phase 3 candidates. npj Vaccines 6(28). https://doi.org/10.1038/s41541-021-00292-w.

Lee J, Kim J (2020) Material properties influencing the charge decay of electret filters and their impact on filtration performance. Polymers 12(3):721. https://doi.org/10.3390/ polym 12030721

Leung WWF, Sun Q (2020) Electrostatic charged nanofiber filter for filtering airborne novel coronavirus (COVID-19) and nano-aerosols. Separation and Purification Technology 116886 https://doi.org/10.1016/j.seppur.2020.116886

Liu D, Ju C, Han C, Shi R, Chen X, Duan D et al (2020a) Nanozyme chemiluminescence paper test for rapid and sensitive detection of SARS-CoV-2 antigen. Biosens Bioelectron 173:112817. https://doi.org/10.1016/j.bios.2020. 112817

Liu C, Zhou Q, Li Y, Garner LV, Watkins SP, Carter LJ et al (2020b) Research and development on therapeutic agents and vaccines for COVID-19 and related human coronavirus diseases. ACS Cent Sci 6(3):315-331. https://doi.org/ 10.1021/acscentsci.0c00272

Mehra MR, Desai SS, Ruschitzka F, Patel AN (2020) Hydroxychloroquine or chloroquine with or without a macrolide for treatment of COVID-19: a multinational registry analysis. The Lancet 395(10240):1820. https://doi.org/10. 1016/S0140-6736(20)31180-6

Mehta M, Prasher P, Sharma M, Shastri MD, Khurana N, Vyas $M$ et al (2020) Advanced drug delivery systems can assist in targeting coronavirus disease (COVID-19): a hypothesis. Medical Hypotheses 144. https://doi.org/10.1016/j. mehy.2020.110254.

Munster VJ, Koopmans M, van Doremalen N, van Riel D, de Wit E (2020) A novel coronavirus emerging in China - key questions for impact assessment. N Engl J Med 382(8):692-694. https://doi.org/10.1056/NEJMp2000929 
NanoBio® Protect Nasal Antiseptic Solution (2020) Available in: https://www.nanobioprotect.com. Accessed in: June 6, 2021

Nanomatrix materials (2021) Available in: https://www.nmmat erials.com. Accessed in: June 6, 2021

Nanotechnology Products Database (2020.) COVID-19 Available in: https://product.statnano.com/. Accessed in: June 6, 2021

Nel AE, Miller JF (2021) Nano-enabled COVID-19 vaccines: meeting the challenges of durable antibody plus cellular immunity and immune escape. ACS Nano. https://doi.org/ 10.1021/acsnano.1c01845

Nooraei S, Bahrulolum H, Hoseini ZS, Katalani C, Hajizade A, Easton AJ et al (2021) Virus-like particles: preparation, immunogenicity and their roles as nanovaccines and drug nanocarriers. Journal of Nanobiotechnology 19(59) https://doi.org/10.1186/s12951-021-00806-7

Novochizol (2020) Aerosol formulation of COVID-19. Available in: https://www.novochizol.ch/. Accessed in: June 6, 2021

Palmieri V, De Maio F, De Spirito M, Papi M (2021) Face masks and nanotechnology: keep the blue side up. Nano Today 37:101077. https://doi.org/10.1016/j.nantod.2021. 101077

Patented anti-microbial NanoDiamonds (ND) mask. 2020. Available in: https://www.master-dynamic.com. Accessed in: June 6, 2021

Pati R, Shevtsov M, Sonawane A (2018) Nanoparticle vaccines against infectious diseases. Frontiers in Immunology 9(2224). https://doi.org/10.3389/fimmu.2018.02224.

Pindiprolu SKSS, Kumar CSP, Kumar Golla VS, P. L, K. SC, S.K. EB, et al (2020) Pulmonary delivery of nanostructured lipid carriers for effective repurposing of salinomycin as an antiviral agent. Medical Hypotheses 143:109858 https://doi.org/10.1016/j.mehy.2020.109858

Polack FP, Thomas SJ, Kitchin N, Absalon J, Gurtman A, Lockhart S et al (2020) Safety and efficacy of the BNT162b2 mRNA Covid-19 vaccine. N Engl J Med 383:2603-2615. https://doi.org/10.1056/NEJMoa2034577

Poole CP, Owens FJ (2010) Introduction to nanotechnology. New Delhi: Wiley India

Powell AE, Zhang K, Sanyal M, Tang S, Weidenbacher PA, Li S et al (2020) A single immunization with spikefunctionalized ferritin vaccines elicits neutralizing antibody responses against SARS-CoV-2 in mice. BioRxiv. https://doi.org/10.1101/2020.08.28.272518

Rao VK (2021) Point of care diagnostic devices for rapid detection of novel coronavirus (SARS-nCoV19) pandemic: a review. Frontiers in Nanotechnology 2:593619. https://doi.org/10.3389/fnano.2020.593619

Refaat H, Mady FM, Sarhan HA, Rateb HS, Alaaeldin E (2021) Optimization and evaluation of propolis liposomes as a promising therapeutic approach for COVID-19. Int J Pharm 592:120028. https://doi.org/10. 1016/j.ijpharm.2020.120028

Reinholz J, Landfester K, Mailänder V (2018) The challenges of oral drug delivery via nanocarriers. Drug Delivery 25(1):1694-1705. https://doi.org/10.1080/10717544. 2018.1501119

Sahin U, Muik A, Derhovanessian E, Vogler I, Kranz LM, Vormehr $M$ et al (2020) COVID-19 vaccine
BNT162b1 elicits human antibody and TH1 T cell responses. Nature 586:594-599. https://doi.org/10.1038/ s41586-020-2814-7

Saunders KO, Lee E, Parks R, Martinez DR, Li D, Chen H et al (2021) Neutralizing antibody vaccine for pandemic and pre-emergent coronaviruses. Nature. https://doi.org/10. 1038/s41586-021-03594-0

Shih H-I, Wu C-J, Tu Y-F, Chi C-Y (2020) Fighting COVID19: a quick review of diagnoses, therapies, and vaccines. Biomedical Journal 43(4):341-354. https://doi.org/10. 1016/j.bj.2020.05.021

Shin MD, Shukla S, Chung YH, Beiss V, Chan SK, OrtegaRivera OA et al (2020) COVID-19 vaccine development and a potential nanomaterial path forward. Nat Nanotechnol 15:646-655. https://doi.org/10.1038/ s41565-020-0737-y

Simone-Finstrom M, Spivak M (2010) Propolis and bee health: the natural history and significance of resin use by honey bees. Apidologie 41(3):295-311. https://doi.org/10.1051/ apido/2010016

The Lancet Microbe (2021) COVID-19 vaccines: the pandemic will not end overnight. The Lancet Microbe Editorial 2(1):e1. https://doi.org/10.1016/S2666-5247(20)30226-3

Udugama B, Kadhiresan P, Kozlowski HN, Malekjahani A, Osborne M, Li VYC et al (2020) Diagnosing COVID19: the disease and tools for detection. ACS Nano 14(4). https://doi.org/10.1021/acsnano.0c02624.

Uzunian A (2020) Coronavirus SARS-CoV-2 and Covid-19. Jornal Brasileiro De Patologia e Medicina Laboratorial 56:1-4. https://doi.org/10.5935/1676-2444.20200053

Valizadeh H, Abdolmohammadi-vahid S, Danshina S, Ziya Gencer M, Ammari A, Sadeghi A et al (2020) Nano-curcumin therapy, a promising method in modulating inflammatory cytokines in COVID-19 patients. Int Immunopharmacol 89:107088. https://doi.org/10.1016/j.intimp.2020.107088

Vasir J, Reddy M, Labhasetwar V (2005) Nanosystems in drug targeting: opportunities and challenges. Curr Nanosci 1(1):47-64. https://doi.org/10.2174/1573413052953110

Walls AC, Fiala B, Schafer A, Wrenn S, Pharm MN, Murphy $\mathrm{M}$ et al (2020) Elicitation of potent neutralizing antibody responses by designed protein nanoparticle vaccines for SARS-CoV-2. Cell 183(5):1367-1382. https://doi.org/10. 1016/j.cell.2020.10.043

Walsh EE, Frenck R, Falsey AR, Kitchin N, Absalon J, Gurtman A et al (2020a) RNA-based COVID-19 vaccine BNT162b2 selected for a pivotal efficacy study. N Engl J Med. https://doi.org/10.1056/NEJMoa2027906

Walsh EE, Frenck RW, Falsey AR, Kitchin N, Absalon J, Gurtman A et al (2020b) Safety and immunogenicity of two RNA-based covid-19 vaccine candidates. N Engl J Med 383(25):2439-2450. https://doi.org/10.1056/NEJMo a2027906

Wang X, Sun W, Yang W, Gao S, Sun C, Li Q (2019) Mesoporous silica-protected silver nanoparticle disinfectant with controlled $\mathrm{Ag}+$ ion release, efficient magnetic separation, and effective antibacterial activity. Nanoscale Advances 1(2):840-848. https://doi.org/10.1039/C8NA0 0275D

WHO (2020b) World Health Organization. Coronavirus disease 2019 (cOVID-19) situation report - 84. Available in: 
https://www.who.int/emergencies/diseases/novel-coron avirus-2019/situation-reports. Access in: July 7, 2021.

Wise J (2021) Covid-19: is vaccination roll out reducing cases and deaths in the UK? The BMJ 372(506). https://doi.org/ 10.1136/bmj.n506

Wu C, Wang AC, Ding W, Guo H, Wang ZL (2018) Triboelectric nanogenerator: a foundation of the energy for the new era. Adv Energy Mater 9(1):1802906. https://doi.org/10. 1002/aenm.201802906

Yan ZP, Yang M, Lai CL (2021) COVID-19 vaccines: a review of the safety and efficacy of current clinical trials. Pharmaceuticals 14(406). https://doi.org/10.3390/ph14050406.

Yang D (2021) Application of nanotechnology in the COVID19 pandemic. Int J Nanomed 16:623-649. https://doi.org/ 10.2147/IJN.S296383

Zhang Y, Zhang H, Wang X, Wang J, Zhang X, Zhang Q (2012) The eradication of breast cancer and cancer stem cells using octreotide modified paclitaxel active targeting micelles and salinomycin passive targeting micelles. Biomaterials 33(2):679-691. https://doi.org/10.1016/j.bioma terials.2011.09.072

Zhang Q, Honko A, Zhou J, Gong H, Downs SN, Vasquez JH et al (2020a) Cellular nanosponges inhibit SARS-CoV-2 infectivity. Nano Lett 20(7):5570-5574. https://doi.org/10. 1021/acs.nanolett.0c02278

Zhang NN, Li XF, Deng YQ, Zhao H, Huang YJ, Yang G et al (2020b) A thermostable mRNA vaccine against COVID19. Cell 182(5):1271-1283. https://doi.org/10.1016/j.cell. 2020.07.024

Zhang R, Hristovski D, Schutte D, Kastrin A, Fiszman M, Kilicoglu H (2021a) Drug repurposing for COVID19 via knowledge graph completion. J Biomed Inform 115:103696. https://doi.org/10.1016/j.jbi.2021.103696

Zhang R, Xu Q, Bai S, Hai J, Cheng L, Xu G et al (2021b) Enhancing the filtration efficiency and wearing time of disposable surgical masks using TENG technology. Nano Energy 79:105434. https://doi.org/10.1016/j.nanoen.2020. 105434

Publisher's note Springer Nature remains neutral with regard to jurisdictional claims in published maps and institutional affiliations. 